Rhode Island College

Digital Commons @ RIC

\title{
Isolation and Community in Short Story Collections by Z.Z. Packer, Jhumpa Lahiri, and Mary Gaitskill
}

Katy A. Howe

Rhode Island College

Follow this and additional works at: https://digitalcommons.ric.edu/etd

Part of the Ethnic Studies Commons, Family, Life Course, and Society Commons, Feminist, Gender, and Sexuality Studies Commons, Inequality and Stratification Commons, Literature in English, North America, Ethnic and Cultural Minority Commons, Race and Ethnicity Commons, and the Sociology of Culture Commons

\section{Recommended Citation}

Howe, Katy A., "Isolation and Community in Short Story Collections by Z.Z. Packer, Jhumpa Lahiri, and Mary Gaitskill" (2006). Master's Theses, Dissertations, Graduate Research and Major Papers Overview. 5. https://digitalcommons.ric.edu/etd/5

This Thesis is brought to you for free and open access by the Master's Theses, Dissertations, Graduate Research and Major Papers at Digital Commons @ RIC. It has been accepted for inclusion in Master's Theses, Dissertations, Graduate Research and Major Papers Overview by an authorized administrator of Digital Commons @ RIC. For more information, please contact digitalcommons@ric.edu. 
ISOLATION AND COMMUNITY IN SHORT STORY COLLECTIONS BY

Z.Z. PACKER, JHUMPA LAHIRI, AND MARY GAITSKILL

By

Katy A. Howe

A Thesis Submitted in Partial Fulfillment

of the Requirements for the Master of Arts

in

The Department of English

School of Graduate Studies

Rhode Island College

2006 


\section{Introduction}

The American short story genre is thriving and provides fertile ground for scholarly discourse. That being said, there is an unfortunate dearth of scholarship in the field. While collections of short stories often receive commendations (for example, Jhumpa Lahiri's Interpreter of Maladies received the Pulitzer Prize in 2000), they do not receive the critical and scholarly attention they deserve. This thesis will examine the story collections of three contemporary women writers: Z.Z. Packer, Jhumpa Lahiri, and Mary Gaitskill.

A recurrent theme in the contemporary American short story in general concerns the tension between isolation and connection/community, a theme that is prevalent throughout American literature and society. As feminist relational psychoanalyst Carol Gilligan explains, Within the context of US society, the values of separation, independence, and autonomy are so historically grounded, so reinforced by waves of immigration, and so deeply rooted in the natural rights that they are often taken as facts: that people are by nature separate, independent from one another, and self-governing. To call these "facts" into question is seemingly to question the value of freedom. And yet this is not at all the case. The questioning of separation has nothing to do with questioning freedom but rather with seeing and speaking about relationships. (xiv-Xv)

Freedom has been misinterpreted as autonomy and separation from others. Instead, freedom should include the ability to have meaningful relationships with others. The tension between connection and separation, or autonomy and intimacy, can be found in many works of American literature, most especially in the short story. Contemporary American women writers, who have greatly enriched the short story genre in recent years, have added their own variations to this thematic tension. I explore those variations through the lens of relational psychoanalysis in three 
collections: Packer's Drinking Coffee Elsewhere, Lahiri's Interpreter of Maladies, and Gaitskill's Because They Wanted To.

The authors of these three collections are all members of marginalized groups: Packer is an African American writer, Lahiri an Indian American writer, and Gaitskill a lesbian writer. In addition to these groups, though, all three writers also belong to the more general group of women who are marginalized by the larger patriarchal society. Bonnie TuSmith, in her study All My Relatives: Community in Contemporary Ethnic American Literatures, concludes that "ethnic literature does indeed offer an alternative discourse, a 'first language' of community rather than isolation" (190). I would like to broaden this statement to apply to any isolated or marginalized group. While ethnic literature includes a large amount of work showcasing the tension between isolation and community, my focus on female writers will show this topic speaks to all marginalized writers and not just those of ethnic literature.

The writers' marginalized status translates into a bone of contention for their protagonists as they struggle with their place within society. The theme that Rocío G. Davis explicates as being common in ethnic fiction is prevalent throughout the fiction of the marginalized: "The two principal thematic constituents of the ethnic short story cycle are the presentation of identity and community, as separate entities, and the notion of an identity within a community -- again, a common theme of ethnic fiction in general" (8). The tension that surfaces because of attempts to be at the same time within and separate from community is prevalent throughout the stories of Packer, Lahiri, and Gaitskill.

In all three collections, the central characters are usually displaced or marginalized from the mainstream society and are often searching for a community in which to define themselves or their identity. While connection with others indeed seems crucial to the central character's sense 
of self, the character often exhibits an ambivalent attitude towards such connection by shunning the very community she craves. Because of her displaced or marginalized status, she develops rigid defenses that protect against the pain of rejection but that also prevent connection or relationship. The search for a sense of individuality within community is a trope that permeates these collections. The tensions that arise in these short stories center on the struggle to find a balance between autonomy and connection/community. The individual must feel separate and independent but, at the same time, connected and emotionally bound to others in order to successfully define her true self.

Regarding the postmodernist argument that there is no "true self," I would like to invoke a particular meaning of "true self" that refers to a person's ability to experience and freely express core emotions. Simply stated, the true self involves the expression of spontaneous, authentic feelings. Often in the stories I discuss here, the protagonists are so guarded and afraid to uncover their vulnerability and painful feelings that they isolate themselves. They yearn to connect to others and to their core selves but find they cannot do so because they are afraid of shameful exposure.

\section{Community and Isolation}

Emotional bonds are particularly important to the character's sense of true self and are more important than being physically included in a group. Emotional connection must be present for the character to identify herself in relation to others. Therefore, to be an integral part of a community she does not have to be in such a community physically or geographically. Kenneth H. Baldwin and David K. Kirby, in their introduction to their study of community and isolation in American fiction, argue that "although no sharp line can be drawn between external and internal worlds, it is clear that the notion of 'community' has steadily become less a matter 
of geography, consanguinity, and visible bonds and more a matter of shared psychological and spiritual states" (x). Community, therefore, is not only a physical state but is also, and more importantly, a mental state where two or more people share connection. However, to be connected emotionally also carries threats. One particular threat lies in the possibility of losing sense of self and assimilating into the other; another threat is the prospect of rejection by the other. The characters in these collections resist some connections because the threat of losing their hard-earned autonomy is too looming. The risks of revealing emotional vulnerability, too, dissuades them from letting others too close. They struggle between the navigation of a physical and emotional sense of community and the need to feel independent from the very same community. Many times, their lack of success in obtaining this balance causes them to retreat or be pushed into isolation, where they then yearn even more for relationship.

Isolation can be caused by numerous factors. An individual can be excluded by a community because of difference, or she can purposely isolate herself from it. Sometimes both conditions exist. In this situation, the isolated individual may attempt to embrace her isolation in an effort to define herself against the community that is isolating her. By isolating herself from the community in which she truly wants to belong, the protagonist develops a sense of control, even if it is illusory. This sense of control often makes it even more difficult for the protagonist to connect because she does not want to risk losing that illusion of control.

Isolation, for the protagonists in these three collections, mostly affects women. As Gilligan has discussed, women are more threatened than men by the prospect of isolation. As a result, women's goal of independence and control can sometimes evolve into a life without connection. This is not the desired outcome for those who seek individuality within community, for when "women move from attachment to continued connection, always developing in context 
of relationships; they experience the goal of 'independence' as lonely and isolating" (Jordan, et al., 153). While this dilemma is more prevalent in women, men, too, struggle to find a balance between individuality and community. Men often find it difficult to participate in relationships because they have been trained by society to obtain autonomy at all costs. The desire for connection and the concurrent yearning for individuality together create a deep tension of human relational life. The tension that results from the pushing and pulling between isolation and community can further isolate the individual. As a result, the individual may pull away from society even further in an attempt to alleviate some of the tension that has accumulated between the need for individuality and for connection. The problematic nature of individual identity in relation to community for the protagonists in these story collections rests in their complementary but opposing needs for community and individuality.

\section{The Short Story Form}

The short story collection, as a form, invokes a sense of community because the reader is confronted with numerous voices and situations in one volume. Even if the characters and locations of each story are different, the gathering of stories in the same collection leads the reader to acknowledge connections. The stories' close proximity melds them together regardless of the different characters, themes, or plots. The term "short story cycle" has been coined in an attempt to define a type of short story collection as "a book of short stories so linked to each other by their author that the reader's successive experience on various levels of the pattern of the whole significantly modifies his experience of each of its component parts" (Ingram 19). The problem with this definition is that it is so broad it could be applied to any volume of stories by a single author: there are threads of similarity among stories in any given collection simply because those stories have been penned by the same writer. To my mind, the term "short story 
cycle" should only be applied to a group of short stories that share the same protagonists, settings, and themes. In a true story cycle, each independent story has the ability to stand on its own but is deeply affected by the other stories in the volume because they all share essential components, such as characters and themes. Examples of true short story cycles are Jamaica Kincaid's Annie John or Sandra Cisneros' $\underline{\text { House on Mango Street. }}$

Maggie Dunn and Ann Morris introduced the term "composite novel" in response to Ingram's definition of the short story cycle. Their definition of a composite novel is "a literary work composed of shorter texts that -- though individually complete and autonomous -- are interrelated in a coherent whole to one or more organizing principles" (2). Dunn and Morris's main distinction from Ingram's definition is that they broaden the scope to include a body of work that is not exclusively prose fiction. Their "composite novel" can be a group of works that includes poetry, nonfiction, fiction, narrative, pictures, and any number of other texts that speak to each other and strengthen the whole text by their inclusion. Their main argument with Ingram's term is that, while their term "emphasizes the integrity of the whole," the term "short story cycle"

emphasizes the integrity of the parts. In addition, a "cycle" in anyone's definition implies cyclical motion, a circular path, a return to the beginning, all of which preclude linear development. Thus the term short story cycle itself is doubly problematic: it not only implies inferior status in the generic hierarchy, but also prescribes or at least suggests generic limitations" (Dunn and Morris 5, original emphasis).

Taking all of this into consideration, I would like to invoke my own definition of a short story collection: a group of short stories that are capable of being totally independent of one another but that are still bolstered by their connections with each other, no matter how fluid those 
connections may be. In the short story collection, the characters, setting, timeframe, theme, point of view, and even style can differ from story to story. The collection allows the stories to be viewed as at once independent and interdependent. The stories stand alone as complete tales with beginnings, climaxes, and endings. They also, however, relate to the other stories of the collection in a collective whole. Distinguishing features that are threaded through the collection, such as the theme of isolation permeating the lives of all the different protagonists, allow the reader to make connections between the stories while still acknowledging their independence.

\section{Relational Psychoanalysis: An Overview}

Relational psychoanalytic theory provides the theoretical lens through which I will explore the dynamic of community and isolation in the three short story collections. Stephen Mitchell describes relational psychoanalysis as follows: "the basic unit of study is not the individual as a separate entity whose desires clash with an external reality, but an interactional field within which the individual arises and struggles to make contact and to articulate himself" (3). Mitchell explains that relational psychoanalysis theorizes individual identity in that it cannot be defined, or has no meaning, outside the larger relational context.

Mitchell argues that mind is composed of multiple factors defined by relationships with others: "mind has been redefined from a set of predetermined structures emerging from inside an individual organism to transactional patterns and internal structures derived from an interactive, interpersonal field" (17). According to Mitchell, mind is purely relational; one's mind develops based on the relationships one has with others, and those external relationships become internal configurations. He states that "relational-model theories view mind as fundamentally dyadic and interactive; above all else, mind seeks contact, engagement with other minds" (3, original emphasis). Mitchell's model, too, assumes that conflict is always involved in relatedness: 
In the relational-conflict model, the antagonists in the central psychodynamic conflicts are relational configurations; the inevitable conflictual passions within any single relationship; and the competing claims, necessarily incompatible, among different significant relationships and identifications. (10)

The short story collections studied here portray protagonists who are seeking contact with others, even though they often have trouble finding ways to make and maintain connection while safeguarding individuality. The conflicts that result are based upon the tension between autonomy and community.

According to relational theorists, individual selfhood, at its most basic level, depends on relationship with others in order to fully develop. Relationships sustain a person's ability to actively and successfully establish a sense of identity. Relation to the other is imperative for true self-awareness:

At the deepest, subatomic level of physical universe, quantum theory tells us, identity is observer dependent; so too in the psychological universe, theorists are increasingly suggesting, identity at the core level of the self is other dependent, and inextricably bound up with human recognition. Like the relational model of the mind, quantum theory presents a model of reality in which nothing is more fundamental than dynamic, interactive patterns and relationships. (Schapiro, Literature and the Relational Self 2) The self is created in relation to the other. The mind processes what it does and does not identify with and develops from that information. Therefore, without relationship, there can be no development and no sense of true self.

Relational psychoanalytic theory is complicated by the tension that results when an individual attempts to form and maintain relationships while still maintaining individuality: "An 
intersubjective theory of the self is one that poses the question of how and whether the self can actually achieve a relationship to an outside other without, through identification, assimilating or being assimilated by it" (Benjamin 80). In other words, is it possible to have an intimate relationship with another without, in some way, being changed by that relationship? One may not totally assimilate into or lose oneself in the other, but it is impossible to be unaffected in some way. The threat of loss of self, or of the other's negative impact on the self, can cause relationships to go awry before they are even given a fair chance at success. The protagonists in many of the stories are caught in this dilemma as they defend themselves against relationships even as they desperately seek them.

\section{Relational Psychoanalysis: The Feminist View}

Integrating relational psychoanalytic theory, like Mitchell's work, with feminist thinkers such as Carol Gilligan and Jean Baker Miller, can bring into focus both psychological and feminist aspects of the dichotomy between isolation and connection. Janet L. Surrey, focusing on the relational effects of women on women, states that a "continuity of relationship necessitates mutual growth, commitment, and responsiveness to the changing and evolving needs of all persons involved" (Jordan, et al., 60). Surrey argues that in order to establish a successful sense of self, one must have intimate, meaningful relationships, and that this is especially important for women because of their emotional need for connection.

Emotional connection is imperative for women's relational development. Alexandra G. Kaplan, Nancy Gleason, and Rona Klein state that "for women the sense of self is refined, enhanced, and strengthened not through a series of separations but through the inner experiences of relationships marked by mutuality and affective connection" (Jordan, et al., 123). These authors, among others, take relational psychoanalysis one step further and bring the focus onto 
women in particular: "[Women] have developed the sense that their lives should be guided by the constant need to attune themselves to the wishes, desires, and needs of others. The others are the important ones and the guides to action" (Miller 61-62). Miller argues that women often define themselves by their ability to give what is needed to others, ignoring their own relational needs. Women, however, need not only to nurture others, but to feel nurtured themselves. Women have been socialized to serve the other for so long that they often forget about their own emotional needs, or at least do not have the vocabulary to articulate or the resources to assert their needs.

Feminist relational psychoanalysts argue that women, because of the way they are socialized, need relationship and community as part of their self-identity even more than men: Boys, [Gilligan] says, will conceive of self in relation to world in terms of separation, autonomy, and control, and will feel most threatened by intimacy; girls, on the other hand, will have a more seamless, interrelational view, and will feel more danger in situations of separation or isolation than closeness. (Schapiro, Literature and the

\section{$\underline{\text { Relational Self 17) }}$}

Gilligan's premise that girls feel safer in community further complicates my analysis of the three collections because some of the female protagonists seem to choose isolation over connection. Yet the protagonists who pull away from community are still paradoxically seeking to connect. They ultimately yearn for personal connection and community despite their defenses against it. They pull away out of fear of rejection or of losing their hard-won autonomy and independence.

How does relational psychoanalysis concerned with women differ from the same concerns with men? Relational psychoanalysis focuses on the need for attachment in order to successfully create a coherent sense of self that is both individual and communal. Carol Gilligan 
argues that "since masculinity is defined through separation while femininity is defined through attachment, male gender identity is threatened by intimacy while female gender identity is threatened by separation. Thus males tend to have difficulty with relationships, while females tend to have problems with individuation" (8). The societal stereotypes of masculinity and femininity have contributed to this breach. Women in American society have been denied succor for their emotional needs because men are tuned to ignore their need for relationship. Men, on the other hand, are able to continue avoiding relationship with no consequence, even though they yearn for and need connection. Jean Baker Miller asserts that We all begin life deeply attached to the people around us. Men, or boys, are encouraged to move out of this state of existence -- in which they and their fate are intimately intertwined in the lives and fate of other people. Women are encouraged to remain in this state but, as they grow, to transfer their attachment to a male figure. (86) Women's reattachment to a male figure may not provide the emotional connection needed in order for women to construct a sense of self in relation to others because men are encouraged to resist the relational state. Society's rules, therefore, dictate the relational difference between men and women. Men are intrinsically led to believe that relationship is unnecessary while women are led to believe that they need relationship with a man. The truth is that both men and women need relationship as relationships constitute their very individuality.

$$
\text { Relational Psychoanalysis and the Short Story Collection }
$$

The field of relational psychoanalysis offers a rich context for literary analysis. Barbara Schapiro asserts that "reading and aesthetic experience involve a relationship with the text or work of art and thus relational-model concepts are especially relevant" (Literature and the Relational Self 23, original emphasis). The connection between reader and text creates a 
relationship or interaction. When the reader is open to the piece she is reading, the relationship with that piece can become strong and personal. The short story collection as a genre supports a relational point of view as the reader is encouraged to connect the stories together in relation to one another as well as in relation to herself. The story collection, like the relational model view of the self, presents individual stories as distinct and separate, and as intrinsically connected to a larger collective whole.

All of the central characters in these three collections search for ways to become a part of a community. The struggle for this sense of inclusion, and the isolation that often precludes it, are aspects that I intend to explore more fully. TuSmith defines the term "community" as "the relatedness and dynamic interdependence of all life-forms rather than the stagnant, conformist vision that the term tends to evoke in a capitalist society [...] the communal does not mean the negation of the individual" (vii). The individual should not get lost in community; on the contrary, connection gives the individual the ability to assert and define self. It is this view of identity in relation to community that the characters in so many of the stories struggle to achieve. In all three collections, protagonists struggle to be included in some form of community. Often, they are so scared of rejection from that community that they do not allow themselves inclusive rights. Like the short story collection, where each piece is independent but made stronger by its inclusion in the whole, these protagonists search for a delicate balance between their separate individuality and their connection to others in a collective community. 


\section{Z.Z. Packer's Drinking Coffee Elsewhere}

Z.Z. Packer's collection Drinking Coffee Elsewhere portrays characters who are most often marginalized by others because of race. They attempt to protect themselves from further rejection and marginalization by rejecting others, ironically isolating themselves even more. Packer's stories explore the tension between embracing one's separateness and individuality in relation to the other and the desire to belong to a community. The central characters often pretend to be someone they are not in order to fulfill their need to belong or they deny that need altogether, foregoing any connection at all. Their self-isolating patterns lead to a sense of void or incomplete selfhood. Packer's characters search for the delicate balance between individual autonomy and community.

The protagonists in this collection, most of whom are women, struggle with their aching need to belong to a community while maintaining a separate identity. Jean Baker Miller argues that an "important aspect of women's psychology is their greater recognition of the essential cooperative nature of human existence. Despite the competitive aspects of any society, there must be a bedrock modicum of cooperativeness for society to exist at all" (41). Without cooperation, there can be no true community. The protagonists of Packer's short fiction all yearn for this cooperativeness.

All of Packer's stories involve a female protagonist who is marginalized by society as well as by her own moves toward isolation. Even though these protagonists crave attention and relationship, they often shy away from any real interaction with others. This allows them to feel they can govern their lives and control their interactions with others. Even though they may believe they are in control, often they are not, and as a result, they are trapped in their own isolation. Packer's collection focuses on the tension between isolation and community through 
issues of race, gender, and relationships. Race is the most prevalent issue and is especially addressed three stories: "Brownies," "Drinking Coffee Elsewhere," and "Speaking in Tongues." Part of the Group: "Brownies"

Subject and object, active and passive, observer and participant, knower and known -- these reversible complementarities have structured the psychoanalytic relationship. (Benjamin xiv)

Jessica Benjamin's statement about the psychoanalytic relationship also fits the patterns of relationship in Packer's story "Brownies." Here, opposites produce a story that is rich in tensions revolving around the issue of community. Laurel, the narrator, struggles with her place in her Brownie troop. While she treasures her place within the small community, she questions much of what goes on. In her relationships with the rest of the troop, she is both subject and object. She is a member of the group who plots to attack another troop and she is also the object of her own troop members' jokes. She is both active and passive in her relationships. She passively joins the activities of the group and goes along with their actions so she is not isolated by the girls. She actively tries to separate from Octavia and Arnetta, the aggressive leaders of the group, by trying to connect with Daphne, the troop's most introspective member. Laurel observes as Octavia and Arnetta rile the other girls to action against Troop 909, and she is forced to participate in the nighttime excursion to ambush the opposing troop. Laurel is indeed both subject and object, active and passive, observer and participant, as she struggles to find her way among these competing positions.

Laurel narrates the story of her Brownie troop and their run-in with Troop 909 at an overnight camping trip at Camp Crescendo. The story's opening lines emphasize the sense of community among the girls: "by our second day at Camp Crescendo, the girls in my Brownie troop had decided to kick the asses of each and every girl in Brownie Troop 909” (1). After just 
two days at camp, Laurel's Brownie troop has formed a solid and unwavering opinion about Troop 909. Their sense of togetherness makes them all act in unison, agreeing to the proposed attack. While two girls, Octavia and Arnetta, lead the pack, the rest of the girls follow suit quickly and unquestioningly. Their connection with the rest of the troop is too important for them to consider questioning their leaders.

Race is an important trope in this story, as in all of Packer's stories. Troop 909 is a white troop and Laurel's troop is black. Racial difference and the experience of exclusion lie at the heart of the girls' insecurities and the tensions that ensue among them and with outsiders. The girls in Laurel's troop feel they need to protect themselves against Troop 909, even though they have had no real indication that the white girls pose a threat. The girls of Laurel's troop have decided to "kick the asses" of Troop 909 because of Arnetta's unconfirmed claim that "she'd heard one of the Troop 909 girls call Daphne a nigger" (5). Daphne, the quiet and reserved girl of the group, does not confirm or deny Arnetta's claim about the name-calling by Troop 909. She simply says nothing, isolating herself from the discussion in which she is the main subject, and lets Arnetta and Octavia decide how they are going to handle the predicament. The other girls never question Arnetta's claims and agree the Troop 909 girls need to be taught a lesson. Their total acquiescence in this decision speaks to their strong need to remain united in their community. The girls have a compelling need to find strength in their own community and to guard that community against all outsiders. The girls' sense of community causes them to isolate themselves from outsiders. Their sense of trust in one another, while superficial, allows them a sense of security from outside threats.

Their lives at home reinforce this exclusivity as the girls are marginalized within their home communities. The white world that exists just blocks away keeps them at a distance: 
"when you lived in the south suburbs of Atlanta, it was easy to forget about whites" (5). Their marginalized and segregated lives have taught them that to be a separate community is a good thing; by being separate from the white world, which depicts some kind of perfection, they are able to form their own tight-knit community. This racial separation also prompts the girls to guard their community against any outside penetration.

When the girls are confronted with the presence of the white Troop 909 at Camp Crescendo, they automatically view them as invaders. Even though the girls have no real territory to claim at Camp Crescendo, they see it as their space and any white person who appears is automatically an outsider (5). Part of the issue between the white girls and the black girls is that, for Laurel's troop, white girls are a rare sight. Even when they first come across the Troop 909 girls, Laurel expresses a sense of wonder and her own distance from the white girls: "We'd seen them, but from afar, never within their orbit enough to see whether their faces were the way all white girls appeared on TV -- pony tailed and full of energy, bubbling over with love and money" (7). Laurel expects these stereotypes to be confirmed once she and her friends get physically closer to Troop 909. She is also expressing the sense of exclusion that her group routinely experiences because of race. She and her friends are separated from others because they are black:

everyone had been to Rich's to go clothes shopping, everyone had seen white girls and their mothers coo-cooing over dresses; everyone had gone to the downtown library and seen white businessmen swish by importantly, wrists flexed in front of them to check the time as though they would change from Clark Kent into Superman at any second. (5) Clearly, Laurel and her friends have a media-based vision of white people and that imaginary vision threatens them because it signifies what they think are unattainable goals. As a result, 
Laurel's troop bristles against the appearance of Troop 909 even before they actually meet.

Even though Laurel is a part of her troop and her race, she struggles to define her individuality by separating herself from the troop. Daphne seems to have already accomplished this so Laurel has a sense of reverence for her. Laurel desperately wants to connect to Daphne because of her individuality and a poem she wrote that obtained a lot of praise: "I thought Daphne and I might become friends, but I think she grew spooked by me whispering those lines [from her poem] to her, begging her to tell me what they meant, and I soon understood that two quiet people like us were better off alone" (7). Daphne isolates herself to maintain autonomy and Laurel finds that perhaps she should do the same instead of relying on the rest of the troop for her sense of self. Nevertheless, Laurel yearns for connection to someone who can offer her a genuine relationship, something her relationships with the other girls lack.

Even though she yearns for individuality, Laurel needs to be included in the group and to feel like part of the community. While her need for community prompts her to stay in the group, she still asserts her independence. She shows her separation through her declaration that she likes the Brownie songs the rest of the troop hates to sing. There is, however, one song that Laurel dislikes as much as the other girls and that song goes, "Make new friends/But keep the oold,/One is silver/And the other gold" (17-18). Laurel's dislike for this song indicates her dislike for her troop mates: "if most of the girls in the troop could be any type of metal, they' $\mathrm{d}$ be bunched-up wads of tinfoil, maybe, or rusty iron nails you had to get tetanus shots for" (18). Laurel obviously doesn't like her troop mates but she remains in their company because of her fear of isolation. Even though her need for individuality pushes her to show her difference from her troop mates and she wholeheartedly disagrees with them on numerous points, her need for community makes her continue her involvement. 
The girls have formed unique signifiers of their closeness and of the importance of their relationships. For example, their use of words that they can hardly understand, let alone spell, speaks to their need for a common thread to tie them together: "trisyllabic words had gained a sort of exoticism within our fourth-grade set at Woodrow Wilson Elementary" (3). Words such as "Chihuahua," "Caucasian," and "asinine" are threaded into the girls' conversations in an attempt to separate themselves and establish their superiority over the rest of the school, and to address their sense of separation from the white world. The girls instinctively look upon any white person in the vicinity as an intruder. At their school, for instance, there is one white boy and Laurel's mention of him is less than welcoming: "Even the only white kid in our school, Dennis, got in on the Caucasian act" (4). She expresses a lack of respect for Dennis and his attempts to include himself in their community by using the special term her girlfriends coined for use as an insult. The girls, then, react in an expected negative manner towards the group of white Brownies who have invaded their space at camp.

When Laurel's troop finally finds the opportunity to confront Troop 909 about the alleged name-calling, Laurel does not want to join the group; she wants to stay with Daphne. Arnetta, however, will not stand for this and tells Laurel, whose nickname is "Snot," that she will not let her stay behind: "No, Snot. If we get in trouble, you're going to get in trouble with the rest of us" (21). Laurel has no choice but to participate: either she isolates herself from the group and risks losing her place in the community or she goes along with the plan and joins the rest of the girls, reaffirming her inclusion. She chooses the latter. On the way to the bathroom, where they plan on confronting Troop 909, Laurel finally feels connected to the rest of the girls: "Even though I didn't fight to fight, was afraid of fighting, I felt I was part of the rest of the troop; like I was defending something" (22). Laurel, in this moment, feels as though she really is part of the 
Brownie troop community. She feels she is defending not only Daphne but her whole community by participating.

Inside the bathroom, Octavia and Arnetta confront Troop 909. Laurel's friends quickly see that the Troop 909 girls are mentally disabled and that they are a very tight-knit community. The Troop 909 girls instinctively flock together to form a cohesive group that protects them against attack. They have an understanding about the protection and support that community can offer the individual. Laurel's group is surprised by the apparent disability of Troop 909. Troop 909's ability to stick together, however, speaks to Laurel's group's own dissatisfaction with the interactions within their own group and they quickly abandon their plan.

On the way home from Camp Crescendo, Laurel and Daphne share a moment of genuine connection: Daphne gives Laurel the journal she won for the poem Laurel admires so much. This small but significant gesture shows a glimmer of the connection between Laurel and Daphne. They both have found their individuality and struggle to maintain that individuality while still being a part of the group. During this trip, Laurel has reconfirmed her place within the troop community but has also separated herself from it through her interaction with Daphne. The girls talk about the Troop 909 incident and realize that, even though they were at camp with white girls, they were still very much isolated from the rest of society because the Troop 909 girls were mentally retarded. They recognize their own marginalization within society when they discuss they way other people stare at them in public places. Arnetta says, "My mama and I were in the mall in Buckhead, and this white lady just kept looking at us. I mean, like we were foreign or something. Like we were from China" (28). The racial exclusion that each girl encounters on an individual level strengthens their ties to each other. They all experience the same prejudices and are bound together in their anger and pain. 
Laurel conveys her own story in which her father asks a family of Mennonites to paint the porch of their house. At first, the girls tell Laurel to keep quiet, but Daphne speaks for the first time in the story and asks Laurel to continue. It is this story that brings Laurel to some understanding about race and about her place in community. When the other girls ask Laurel why her father asked the Mennonites to paint only the porch and not the whole house, Laurel remembers that her father had said that, "it was the only time he'd have a white man on his knees doing something for a black man for free" (30). Laurel recognizes that "there was something mean in the world that I could not stop" and that racism permeates every person (31). Her inclusion in the racial group to which she belongs will always exist, even though she knows racial barriers are a societal construct.

Laurel understands her place in the troop more fully through the tensions between her, the others in her troop, and outsiders. In discussing the psychoanalytic relational model, Barbara Schapiro states that,

Conflict is always implied in relatedness. Ambivalence and conflictual passions revolving around issues of autonomy and dependence are inevitable in any single significant relationship; and conflict is equally unavoidable among the competing claims of different significant relationships in one's life. (Literature and the Relational Self 3) Tensions are inevitable in relationship. Laurel yearns to connect to Daphne but Daphne is too isolated and, therefore, there is tension for Laurel as she tries to define herself in relation to others. Daphne, while part of the group because of the protective actions the rest of the girls perform on her behalf, distances herself from the group. Both Daphne and Laurel need individual autonomy; Laurel's tension lies in trying to balance that individualism and being part of the group. At the end of the story, Laurel has recognized her need for individuality through 
her interactions with Daphne and has reaffirmed her need for community by remaining part of the troop.

\section{A Place of Her Own: "Drinking Coffee Elsewhere"}

The sense of self is tied not to a belief in the efficacy of aggression but to a recognition of the need for connection. (Gilligan 49)

Told from the first person point of view, "Drinking Coffee Elsewhere" introduces Dina, an intellectual who is isolated from her lower class black community, where it is not even acceptable to read: "on Greenmount Avenue you could read schoolbooks -- that was understandable. The government and your teachers forced you to read them. But anything else was antisocial. It meant you'd rather submit to the words of some white dude than shoot the breeze with your neighbors" (131-32). Dina is isolated from her own community because of her intellect and because of the fact that she always has a book in her hand. Her reaction to this isolating treatment is to further isolate herself from them. She puts up an aggressive front to guard her true feelings from the judgmental and assuming views of others. By separating herself from the rest of the community, Dina constructs a life that is seemingly void of the need for others. She denies the need for connection, thus denying her own ability to define her true self.

The story opens at Yale University's Orientation Day. The group games attempt to induct Dina into a community of first-year students where their shared experience of shyness and insecurity brings them together. This type of community, however, is superficial and falsely connected. One of the first games that the group is asked to play is a game called "Trust": "The idea was that if you had the faith to fall backward and wait for four scrawny former high school geniuses to catch you, just before your head cracked on the slate sidewalk, then you might learn to trust your fellow students. Russian roulette sounded like a better way to go" (117). Dina's 
attitude towards this game is one of obvious disdain and she immediately isolates herself in a way that will be her trademark defense throughout the rest of the story: "No fucking way" (117). The orientation leader, a lithe platinum blond, quickly tells Dina that her decision is perfectly understandable and that "as a person of color, [Dina] shouldn't have to fit into any white, patriarchal system" (118). In the first scenes of the story, Dina has not only isolated herself from the rest of the student body by refusing to participate in the orientation game, but has been isolated by the other students. Dina has already been labeled as separate because of her race, and for that reason she is told she may refuse to participate, furthering her isolation.

After another grueling game of get-to-know-you in which each student names an inanimate object they would like to be, Dina is sentenced to a year's worth of psychiatric counseling, weekly meetings with the Dean, and residence in a "suicide single" because of her choice of object: "My name is Dina, and if I had to be any object, I guess I'd be a revolver" (118). Her choice of object shows Dina's need for attention, even if it is negative. Dina is able to get attention by shocking those around her with such comments. The statement also shows Dina's blatant hostility which is part of her coping mechanism. As part of the assigned program, the female counselors are told to check in on Dina every other day. In an effort to isolate herself entirely, Dina persuades them that the visits are unnecessary: "By the second week, I had made a point of sitting in a chair in front of the door, just when I expected a counselor to pop her head around. This was intended to startle them. I also made a point of being naked. The unannounced visits ended" (120). Dina's attitude towards others is clear: she resists connection and prefers her self-inflicted isolation. During her first year at Yale, though, Dina has difficulty staying isolated.

One girl constantly attempts to connect to Dina. When Heidi knocks on her door 
unexpectedly, Dina does not even want to let her in, let alone start a relationship with her. Heidi quotes some poetry from their Contemporary Poetry class:

"When I was a child," the person said, "I played by myself in a corner of the schoolyard all alone. I hated dolls and I hated games, animals were not friendly and birds flew away. If anyone was looking for me I hid behind a tree and cried out 'I am an orphan--."” (121) Dina opens the door and accuses her of plagiarism, saying that she knew the poem because "it was one of the few things I'd been forced to read that I wished I'd written myself" (121). Having succeeded in getting Dina to open the door, Heidi immediately asks if Dina wants to go to Commons to get dinner (121). Pointing towards a "pyramid of ramen noodle packages," Dina says, "that means I never have to go to Commons. Aside from class, I have contact with no one" (123). Dina works hard for her isolation and prides herself on it. She sees isolation as a way to protect herself from rejection and harsh judgment from others. Her interest in the poem Heidi quotes speaks to her feelings of aloneness, which are inflicted by society and her own actions, and the way she works to maintain that isolation.

Even though Dina constantly tries to push Heidi away, Heidi does not give up. After mentioning a disease that could inhabit refrigerated and reheated ramen noodles, Heidi convinces Dina to go to Commons to eat. Dina "wondered why [Heidi] even bothered, and was vaguely flattered that she cared" about her well-being (124). Dina starts to open up to the connection but quickly retreats by undermining everything Heidi says. Unfazed, Heidi puts her arm around Dina's shoulders and continues to walk with her. Even though Dina swears she will "have to chop it off" next time, she admits to herself that "in the cold air, her arm had felt good" (125). The concession to the comfort of Heidi's arm shows Dina yearns for connection. Dina wants to feel connected to someone who has the ability to understand her and to sympathize with her. 
Heidi seems to have those qualities. Dina, however, feels that she has to put up a protective front to guard against the possibility of rejection or of being hurt and continues to block Heidi from really getting to know her. It is not just Heidi that Dina blocks, though.

As the days go by, Dina finds herself more embedded in her relationship with Heidi. While talking to Heidi at Commons, Dina finds herself able to predict Heidi's mood and attitude because she recognizes Heidi's different facial expressions. Their relationship has developed and they are both invested in the friendship. While the girls are eating, a young man approaches and extends a written invitation to a gay and lesbian party. Dina is offended and shocked that anyone would think she was gay. Dina's automatic disgust at the mention of homosexuality shows how affected she is by societal expectations and how she tries to fit into those expectations. She denies herself inclusion in a community that would have welcomed her.

While she shuns inclusion in most groups, Dina does take steps to open up to Heidi. The girls apply to be dishwashers in the food hall so they can work together. After washing down the floors on a winter's evening shift, Dina, surprisingly, takes a step in furthering their relationship by taking off her clothes. She justifies her actions to Heidi by saying that "its too cold to go outside with our uniforms all wet. We could just shower here. There's nobody but us" (137). Dina is finally letting her guard down and is allowing herself to be open and vulnerable with Heidi. Even though Dina takes off her clothes and then urges Heidi to do the same, their relationship never reaches the sexual plane. Their nakedness reflects an emotional openness and intimacy.

Once Dina succeeds in convincing Heidi to take her clothes off, she tells her to "“Open up,' I said, 'or we'll never get done'" (138). Dina wants Heidi to open up, though the command is also what Dina yearns but fears to do herself. She forces Heidi to expose herself physically by 
throwing the soap bottle at her. Heidi was using her arms and hands to cover her breasts and genitalia. In order to catch the bottle Dina throws at her, she has to fully expose herself. Dina has an epiphany about her relationship with Heidi that night: "I think I began to love Heidi that night in the dish room, but who is to say that I hadn't begun to love her the first time I met her? I sprayed and sprayed her, and she turned over and over like a large beautiful dolphin, lolling about in the sun" (138). Dina accepts this relationship and seems ready to expose herself to Heidi. She is a vulnerable person and her move to make Heidi show her own vulnerability shows an attempt to be on the same plane as her friend. This will eventually lead to a more concrete connection.

Dina and Heidi spend more and more time together over the course of the school year: "we spent the winter and some of the spring in my room -- never hers -- missing tests, listening to music, looking out my window to comment on people who wouldn't have given us a second thought" (140). The two girls have come to a level of comfort with their relationship and with their isolation from the rest of the school community. By staying only in Dina's room, the suicide single, the girls are able to cut themselves off from the outside world whenever they wish. The bond they develop is strong, but not so strong that it will never break. It seems to be, however, the strongest relationship Dina has ever let herself be a part of since her mother's death. Janet L. Surrey argues that "continuity of relationship necessitates mutual growth, commitment, and responsiveness to the changing and evolving needs of all persons involved" (Jordan, et al., 59). The interaction between the two girls facilitates their growth and strengthens their connection. However, that connection is very fragile because of Dina's fear of rejection and is lost much more quickly that it was gained.

A major reason the relationship between Dina and Heidi eventually fails is because Dina 
is unaware of, or at the very least unsure of, her sexuality. Stephen Mitchell argues that "the relational model does not negate the importance of conflict nor of bodily, sexual experience so fundamental to the classical model. Rather, it argues the significance of conflict and sexuality as both implicit in and shaped by the larger relational matrix" (Schapiro, Literature and the Relational Self 3$)$. While it is not necessary to be sexual in a relationship, sexuality embodies one's deepest relational nature. Dina's lack of sexual self-awareness, then, prevents her from identifying with Heidi on a level deeper than what they have already established. Even the dishwasher room scene, where both girls are naked, shows no sexuality on either girl's part. Dina shrinks from acknowledging her sexuality because she is afraid of opening up on the deepest relational level.

Dina's confidence in her relationship with Heidi vanishes once she sees Heidi get up at the podium on Coming Out Day at school and assert her sexual preference. Given her previous negative disposition towards anything suggesting homosexuality, it is not surprising that Dina is infuriated and embarrassed by Heidi's involvement in the program, and she immediately cuts all ties to her one and only friend. She feels betrayed by Heidi because of her limited tolerance for homosexuality. Only with the passing of Heidi's mother does Dina finally acknowledge Heidi again and allow her back into her life. Unfortunately, Dina has reverted back into her state of isolation and this prevents either girl from reconnecting.

When Heidi asks Dina to accompany her to Canada for her mother's funeral, Dina halfheartedly sees this as an opportunity to reformulate the connection she lost with Heidi. Dina, however, cannot reconnect to Heidi as she demonstrates with cutting remarks about Heidi's mother's death. Heidi, understandably, is not as receptive to Dina as she was before. Dina observes that Heidi "seemed thinner and meaner; every line of her body held me at bay" (145). 
Dina isolated herself after seeing Heidi on the podium at the Coming Out rally and Heidi, in turn, isolates Dina by refusing to let her close.

Part of Dina's inability to connect stems from her loss of connection with her mother. Dina watched her mother die slowly from what doctors described as kidney failure, but Dina's own diagnosis is that her father had slowly killed her mother: "he made her so scared to live in her own home that she was finally driven away from it in an ambulance" (129). Her mother's death leaves her feeling vulnerable, alone, and distrustful of others. Another episode in Dina's past can help to explain why she is so reluctant to form relationships with others. When she was a young girl, Dina's embarrassment about her social situation caused her to go to another neighborhood to do grocery shopping: "I hated those cashiers [in my hometown], and I hated them seeing me with food stamps, so I took the bus and shopped elsewhere" (132). She meets a young boy, Cecil, while walking home from the grocery store. She notices that he has beautiful shoes, and that isolates her from him because the shoes suggest a greater affluence than her own. Cecil attempts to cultivate a connection with Dina by asking her name and if he can help her carry her groceries home. While she is flattered by his advances, Dina runs from him and his suggestion of connection, dropping her groceries. Dina leaves the groceries on the sidewalk, knowing full well that she could easily clean the eggs off of the rest of the groceries when she returned home. Dina's humiliation in front of Cecil reflects her utmost fear of loss of control. Echoing the shower scene with Heidi in the dining hall, running from Cecil shows Dina's vulnerability and fear of connection. As she is reciting this particular story to her psychiatrist she lies and tells him she let Cecil walk her home and that she then made out with him. She admits to herself that, "I had not wanted the boy to walk me home, that I didn't want someone with such nice shoes to see where I lived" (133). Dina isolates herself from Cecil by running 
away. She also isolates herself from her doctor by lying to him. Dina's defense mechanism is to isolate herself from everyone around her, even if the other person does not pose an immediate threat.

At the end, Dina does not go to Canada with Heidi to her mother's funeral because of Dina's cold comment about her death. Dina drops out of Yale and moves in with an aunt. Every day, however, she "imagined Heidi's house in Vancouver" and how wonderful it would be to visit Heidi there. She fantasizes about Heidi coming to visit her one more time: "Just me in my single room. She knocks on the door and says, 'Open up"' (147). Dina obviously wishes for the relationship she had with Heidi. She realizes her need for that connection. Unfortunately, she cannot have it back because her self-isolation finally created an irreparable breach. In this story, the yearning for connection is superseded by fear, shame, and a self-protective isolation.

\section{Faith in Others: "Speaking in Tongues"}

It now seems clear we have arrived at a point from which we must seek a basis of faith in connection -- and not only faith but recognition that it is a requirement for the existence of human beings. (Miller 88)

As relational psychoanalysts stress, connection with others is needed for an individual to develop. In Packer's “Speaking in Tongues," the protagonist, Tia Townsend, must rely on her connections with strangers to find her identity and place within society. Tia is introduced at her home in Montgomery, Alabama. Her life is very much based in her Aunt Roberta's church, and she is forced to wear long skirts and high shirts that isolate her from the rest of the more modernly dressed student body at Rutherford B. Hayes High. The church's strict impositions are paired with high expectations. Tia and her best friend, Marcelle, who is a member of the same church, have not yet been able to speak in tongues, an act that is seen as a marker of a close, 
personal relationship with God: "You could only truly speak in tongues when all worldly matters were emptied from your mind, or else there was no room for God" (151). Since the girls have not been able to speak in tongues, they are isolated from the rest of the church community who believe the girls have not accepted God. Marcelle is seen as a "bad influence" and Tia's connection to her pulls her further away from the church community (150).

As punishment for allegedly mocking God and the Sunday School textbook, Tia is taken to the hymnbook closet by her teacher to recite and receive prayers. Sister Gwendolyn tries a "more aggressive sort of laying-on-of-hands," an action intended for those who stray from the church's teachings (153). This attempt to save Tia's soul is largely in vain, because when Sister Gwendolyn orders Tia to "say the Lord's Prayer. I want you to cry tears for Jesus," Tia cannot do so (154). Tia is not open to a relationship with God by this church's standards and does not see the importance that her aunt and the rest of the community place on that relationship. The closet experience with Sister Gwendolyn is the final push for Tia and confirms the loss of connection between Tia and the church. She can no longer sit idly by and let her life be ruled by those with whom she doesn't agree. As a result, Tia decides to leave her home and travel to Atlanta to find her mother who abandoned her as a child and left her in her Aunt Roberta's care.

Tia's connection, or lack thereof, with her mother provides the basis for all of her relational difficulties. Tia yearns for connection with her mother and desperately wants it to be rekindled. The breach in this primal relationship understandably limits her development. Tia needs affiliation with her mother because it would fulfill a basic need for connection. Jean Baker Miller states that, in American society, "affiliation is valued as highly as, or more highly than, self-enhancement. Moreover, it allows for the emergence of the truth: that for everyone -- men as well as women -- individual development proceeds only by means of connection" (83, original 
emphasis). Because of the broken relationship with her mother, Tia desperately seeks nurturing connections with others. When she finds she cannot maintain connection with anyone in her social circle, Tia grasps at the fleeting relationship she remembers she has with her mother.

Throughout her narrative, Tia reminisces about her mother. After receiving a free meal at McDonald's from a stranger who tells her she is pretty, Tia recalls a time when she was five and her mother called her the same. Tia hangs onto these shreds of recollection in the hopes that the relationship with her mother can be renewed. Tia had resigned herself to her situation with her aunt in Montgomery, but the memories of her mother remain. Tia knows that "they [her church family] loved her and she loved them, but it was a smothering sort of love: love because you had to, never getting the chance to find out whether you wanted to or not" (168). The love her church community offered was forced and oppressive, and so she rejects it in an attempt to assert her individuality.

On the day Tia decides to go to Atlanta, she packs her bag, grabs her clarinet, and, instead of going to school, walks to the bus station. Her friend Marcelle meets her there for moral and financial support. While in the bus station, Tia is confronted with racism and the fact that not much has changed since Dr. Martin Luther King, Jr. was alive. Commenting to herself on the dated décor, Tia thinks that "perhaps this was exactly how it looked when King lived here, and she tried to imagine where the 'Colored' and 'Whites Only' signed would have hung, then she realized she didn't have to. All five blacks waited in one area, all three whites in another" (156). Segregation still exists in Tia's world, even though it is no longer legal; it is an unconscious aspect of American public life. This is the first time Tia has been exposed to the racial prejudices inherent in American society. Marcelle, however, has already had such an experience. When the girls say their farewells, Tia becomes worried that if they make a 
spectacle and hug, the white bus driver might remember and report them. Marcelle retorts that, "we all look the same to them anyway" (158). Marcelle has come to the conclusion that there is a clear distinction between black and white in American society, and one group is hardly concerned with the other.

The bus ride to Atlanta offers Tia her first taste of feeling truly connected to a group or community of others. After a pit stop at a Burger King, the driver drives off, leaving a passenger behind because he took longer than the allotted fifteen minutes. The passenger chases the bus and the driver teasingly stops, only to drive off again once the passenger nears the doors. The other passengers on the bus castigate the driver for his behavior. They threaten to report the driver, bang on the windows, and cheer on the runner. After doing this twice, the driver finally allows the deserted passenger to board the bus. The camaraderie among the passengers on the bus was unfamiliar to Tia. She says,

it was different from church, where everyone felt something she wished she could feel but didn't. She thought she felt God the most when she was quiet, or when she wondered whether there was a God at all. But here on the bus, everyone was rooting for a man whom none of them knew, but there he was, real and running. When everyone began banging the windows as if to break them, she banged on them too. (160-61)

Similar to Laurel's feelings of inclusion in the dark outside the camp bathroom in "Brownies," Tia feels exhilarated and strengthened by this communal experience. Even though the bus passenger community is quite temporary, it is clear that Tia yearns for this type of mutual connection. In contrast to her church experience, this incident inspires genuine faith in community as everyone pulls together and roots for the abandoned stranger. Tia, an abandoned child herself, finds hope in the communal support of the bus passengers. 
After reaching Atlanta, Tia searches the phonebook and finds four listings that could lead to her mother. After calling three numbers and getting no positive response, Tia decides to give up for the night. Hanging up the phone and closing her eyes for a moment, "she did not know why she'd expected there to be fewer people, less noise, less ugliness when she opened them again, but she had" (163). Tia wants to separate herself from all that is going on around her. She is no longer connected to her fellow bus passengers and she is once again alone. She attempts to isolate herself from those around her as a coping mechanism; isolation offers her the illusion of protection and safety.

Tia's desire for protection leads her to Dezi, who reminds her of her connection with her mother because he called her pretty the first time they met. Dezi, who buys her dinner at McDonald's and then returns the following day to take care of a wound, convinces her that she can trust him and she accompanies him back to his apartment. While she is constantly questioning her interactions with Dezi and at times distrusts his actions, Tia wants to believe that Dezi is a good and generous man and that he would never do anything to harm her: "she couldn't believe how wrong she'd been about Dezi. She was no better than her aunt Roberta, who railed against all men who weren't church members, calling them low-life no-good, no-account fathers. A surge of affection rose in her for Dezi, for his protectiveness, for the pain in his eyes" (17677). Tia's innocence allows her to believe she is safe with Dezi, even though the reader quickly gathers that he is a dangerous pimp. At Dezi's apartment, Tia tells him that she is looking for her mother and, when he makes a joke about her plight, she starts to hit him. She quickly feels bad about hitting him, "but doing so made her feel closer to Dezi, as though they'd weathered some ordeal together" (184). Tia's need for relationship leads her to find it in even the most unsuitable of connections. Her violent outburst towards Dezi, who had misled her about her 
mother's whereabouts, makes her feel more connected to him.

While Tia finds some solace in her relationship with Dezi, it is her connection to Marie, one of Dezi's whores, that saves her and ultimately sends her back home. Tia meets Marie when she comes out of the bathroom in Dezi's apartment and finds the scantily-clad Marie sitting on the sofa. Immediately, Marie connects with Tia. She comments on the heat of the apartment and, taking off her clothes, asks Tia if she too is hot. She quickly answers her own question, though, saying "I don't even have to ask if you hot. Black folks always hot" (187). This instantaneous connection on the basis of shared racial experience wins Tia over immediately and she attaches herself to the older woman. Tia assumes that Marie is Dezi's girlfriend and this makes Marie laugh, pushing Tia's shoulder "as though they were longtime friends" (188). Tia clings to the shreds of connection Marie offers her. However, Tia's relationship with Marie is more superficial than it seems. After Tia and Dezi almost make love, for example, Tia searches for Marie so she can confess her intimate relationship. Marie, however, jealously turns on her and devalues Tia's connection with Dezi. Tia's shallow relationship with Marie is questionable but she clings to it because it is all she has.

Tia's need for connection, unfortunately, keeps her going back to Dezi. After a fight with him, Tia flees his apartment and makes her way to the bus station where she plans to stash her bags until she can find another place to stay. Dezi finds her at the station and, at first, Tia shies away from his advances. Even so, she soon gives in and returns to his apartment, showing her need for connection, however exploitive or self-destructive: "she had felt nothing but anger for him that morning, now she felt the relief of seeing someone familiar" (191). Her need for familiarity and connection overrides the intuition that told her to leave Dezi's apartment in the first place. 
Back at his apartment, Dezi is able to get Tia onto his couch, naked, and is almost able to have his way with her when "she knew that this was her chance, like birth, to be part of someone. Then it hit her with a sadness: if sex and birth meant being part of someone, then death meant you belonged to nobody at all" (193). Her yearning for connection and her pseudo-connection to Dezi bring her to a profound realization about the ultimate aloneness we all face as mortal beings. Tia's connection with Dezi, however shallow and questionable, leads to genuine selfknowledge and an astute realization about human isolation. Such an understanding of ultimate human aloneness forms the backdrop for all of Packer's characters as they pursue connection and relationship. Tia's desperation for connection makes her almost give into Dezi's advances as she thinks that sex is a way towards a deep connection.

Even after her revelation about connection, Tia refuses Dezi and falls asleep on his couch. When she wakes up and takes stock of her body and her situation, she assumes Dezi has taken advantage of her. Terrified and enraged, she attacks Dezi with a knife and cuts him. She acts before she even gets the facts; he had not violated her. Though she yearns for a genuine relationship, Tia finds herself in a frightening world with which she is not equipped to deal. In a blind rage, she runs out of the apartment and luckily runs into Marie. Marie inspects Tia's genitals to make sure that Dezi did not actually have sex with her. Marie tells her that she is sending her home: "We can't have people like you running around here" (205). Though she so recently had thwarted Tia's ideas of relationship with Dezi and made it seem as though Tia was a nuisance, Marie goes out of her way to help the poor runaway. In an attempt to make Tia feel more at ease, Marie rambles on about the new condominium complex that is being built close by: “Tia knew the only reason Marie was talking so much was to keep her company, but she couldn't bring herself to say anything" (205). Tia enjoys this exchange of information and she feels once 
again connected to someone. As Marie talks to Tia, she makes Tia believe that she is being included in something and that she belongs.

Marie helps Tia further by commanding some of her friends to give the young girl money for her trip back to Alabama. At first the women refuse the appeal, but they ultimately submit to Marie's abusive and persuasive arguments. The community of prostitutes work together to make sure Tia will have a safe trip home. Their ability to cooperate with each other to help another person shows faith in human connection, which is similar to the bus incident. When Dezi, bleeding from Tia's cuts, reappears and tries to get Tia back, the women band together to save Tia by pinning Dezi to the ground, all the while entreating Tia to run away. She finally heeds their entreaties, but not before giving Marie a thankful hug. This group of women, while societal outcasts and individually tough, form a community in order to protect Tia.

This story expresses faith in human relationships despite its portrayal of abandonment, exploitation, and abuse of which humans are capable. Tia needs connection so badly that she risks her own life by going to Atlanta by herself to look for her mother, trusting in a stranger who is a smooth-talking pimp, and then trusting a group of prostitutes who would not have helped her individually. Yet as a group or community, the women do protect her, offering Tia one final glimpse of the potential in community. In this story of an abandoned, runaway child in a dangerous, self-serving world, Packer affirms her belief in human connection and community. 


\section{Jhumpa Lahiri's Interpreter of Maladies}

Jhumpa Lahiri's collection Interpreter of Maladies depicts displaced immigrant protagonists or second-generation Indian American characters searching for a way to fit into a community while still maintaining individuality. Living in communities that are dissimilar from the culture they grew up in, even if they grew up in America, these characters often feel set apart from the places in which they should be able to feel at home. Lahiri's collection "explores the ethnic character and history of a community as a reflection of a personal odyssey of displacement and as a search for self and community" (Davis 7). This displacement often leads to an inability to make connections on an intimate level. Nevertheless, Lahiri's characters often struggle against their deep sense of isolation as they yearn to nurture and rekindle connection.

Lahiri's characters, many of whom were born and raised in the United States, were brought up in the Indian tradition and live their lives according to the parameters of that tradition. The pushing and pulling between cultures results in much tension in the protagonists' lives as they attempt to mediate between old-world demands of tradition and new-world demands of contemporary living and relationship. Lahiri calls this the "shuttling between two dimensions that [have] nothing to do with one another" ("My Two Lives"). Her characters grasp at the most elusive of connections just to feel as though they have some kind of relationship. These relationships, however superficial, do serve a purpose for the protagonists. Though the relationships can cause pain, they often lead the protagonists to an epiphany about the illusions in their lives and that they are searching for a sense of connection that is much more genuine. When the protagonists come to realize the illusions are just that, the connections they thought they had are shattered.

In two of the stories discussed here, the main protagonist is male. American society 
emphasizes the need for men to be autonomous and self-sufficient. It is much more acceptable for women to be concerned about their relationships than it is for men. The idea that males have less need for fulfilling relationships in their lives, however, is a social construct and does not address the actual male need for relationship. Jean Baker Miller argues that "men's only hope lies in affiliation, too, but for them it can seem an impediment, a loss, a danger, or at least second best" (87, original emphasis). Lahiri's male protagonists show that men need relationship and that they too struggle with the tension between individuality and connection.

Lahiri's collection focuses not only on men and women's struggle to create connection but also on the loss of connection between people. Grief or an intense sense of loss can cause a breach in connection. Relationships that are built on a connection that is not mutual or stable have a minimal chance of success. Lahiri's characters, regardless of this instability, will even search for a sense of connection to people they hardly know for the sense of security it provides. Noelle Brada-Williams argues that "a sense of exile and the potential for -- and frequent denial of -- human communication can be found in all of Lahiri's short stories" (454-55). The central characters struggle with their isolation and yearn for relationship, even though it is often denied them. The protagonists in "A Temporary Matter," "Interpreter of Maladies," and "Sexy" all grapple with a sense of displacement and a deep yearning for connection.

\section{Trying to Connect: “A Temporary Matter"}

Relationship requires connection. It depends not only on the capacity for empathy or the ability to listen to others and learn their language or take their point of view, but also on having a voice and having a language. (Gilligan xix-xx)

In “A Temporary Matter," Shoba and her husband, Shukumar, struggle with their relationship after the loss of their son, who was stillborn. Their understandable grief makes it 
impossible for them to continue their relationship as it was before the baby's untimely death.

The loss stifles both characters and they are unable to speak to each other or to anyone else about their feelings or needs, rupturing the connection they once enjoyed. These factors, as Gilligan points out in the above quote, are necessary for true connection. After the stillbirth, Shoba and Shukumar lose that capacity.

The story is told from the third person limited point of view and, as a result, the reader is exposed only to Shukumar's thoughts and feelings. Having a male's perspective on this awful situation offers the reader a detached view of Shoba's ordeal, and her isolation is emphasized because of this. Shoba isolates herself not just from her husband, but from society in general until she feels she is ready to interact with others. The male narrative perspective also emphasizes her isolation because she is detached from the reader. We only see her through Shukumar's eyes as a distant figure whose inner life is inaccessible. In addition, the male point of view reveals that men need connection as much as women. Even though it is not as accepted in American society for men to admit their need for relationship as it is for women, that need is still present. Shukumar is hurt by the loss of his connection with Shoba and yearns for the reinstatement of that relationship. As Shoba deals with the loss of her son, she isolates herself totally from Shukumar. Both characters are involved in their pursuit of isolation and they become "experts at avoiding each other in their three-bedroom house" (4).

The story opens with a description of the neighborhood in which the couple lives. They have received a notice that everyday for a week the power will be shut off for an hour at eight o'clock in the evening to repair lines that were damaged in the recent snowstorm. The very description invokes a sense of isolation from the outside world: "The work would affect only the houses on the quiet tree-lined street, within walking distance of a row of brick-faced stores and a 
trolley stop, where Shoba and Shukumar had lived for three years" (1). Their street sounds like the typical American neighborhood with its tree-lined streets and easy access to shops and transportation. However, because the electrical work will only affect this one street, they are separated from the rest of the city, emphasizing their seclusion and setting up the deep separation that exists between the husband and wife.

Following the separation of their street from the rest of the community, the reader is shown that there is a deep chasm between Shoba and Shukumar. Shoba returns home from the gym with her makeup smudged and, in places, worn off. Shukumar reminisces about past times: "she used to look this way sometimes, Shukumar thought, on mornings after a party or a night at a bar, when she'd been too lazy to wash her face, too eager to collapse into his arms" (1-2). Shukumar yearns for that level of connection again. He feels isolated from his wife and yet does nothing to try to connect to her. In fact, he delves into his own type of isolation. Using the snowstorm as an excuse for staying inside, Shukumar stays in the house for days on end, "not even leaving to get the mail, or to buy fruit and wine at the stores by the trolley stop" (2). Shukumar, while he yearns for the connection he once had with Shoba, isolates himself from the outside world and from Shoba in any way he can.

Before the tragedy, Shoba and Shukumar seemed to have a strong connection as husband and wife. After the baby's death, though, they allow that connection to dissipate, leaving just memories of how they used to be together. Grief and the couple's lack of ability to deal with grief ultimately doom their relationship. Psychoanalyst Marilyn McCabe states that

Grief experience also often includes a paradoxical set of responses: belief and disbelief, denial and acceptance, yearning and despair, disintegration and reintegration of self and world. Further, there is often a tension, oscillation, or recursive kind of movement 
between various degrees of belief and disbelief, desire and absence, yearning and despair, pain and relief, aspects of grief that are seemingly contradictory but that, paradoxically, make each other possible. (132)

There must be a delicate balance among all of these opposing feelings and responses for a relationship to be successfully maintained and for grief to be dealt with in a healthy manner. These complementary emotions, however, are largely ignored by both Shoba and Shukumar. As a result, they are both unable to connect to each other on a level anywhere near what they had achieved prior to their baby's death. The stillbirth begins their downward spiral as Shoba and Shukumar are isolated from the rest of the hospital population. Shoba had been given a room "in a wing of the hospital they hadn't been to on the tour for expectant parents" to recover from the ordeal (3). The unspeakable tragedy that has occurred to them has caused them to be cut off by society. Shukumar struggles with Shoba's actions after the baby's death. He cannot explain the changes that appear to take place within her: "he thought of how long it had been since she looked into his eyes and smiled, or whispered his name on those rare occasions they still reached for each other's bodies before sleeping" (5). Because of these changes, he simply tries to avoid her. Rather than trying to save the relationship that they had once enjoyed, they both allow themselves to sink further and further away from each other into a state of almost complete separation. They do not allow themselves the language needed to repair the chasm that has formed between them.

The only attempt Shoba makes at having any contact at all with her husband is when she visits him in his study before going to bed:

She would rest her hands on his shoulders and stare with him into the blue glow of the computer screen. "Don't work too hard," she would say after a minute or two, and head 
off to bed. It was the one time in the day she sought him out, and yet he'd come to dread it. He knew it was something she forced herself to do. (8)

Like his wife, Shukumar has taken steps to isolate himself. One major step he takes is setting up his study in the room that was going to be the baby's nursery. He admits that he set up his workspace in that room "partly because the room soothed him, and partly because it was a place Shoba avoided" (8). Their relationship is severed because both of them work to isolate themselves and make no genuine effort to reconnect, even though Shukumar ultimately yearns for the reconnection.

Their separate work spaces are not the only factors that work towards their further isolation from one another. Food, an image that is used widely in Lahiri's collection, becomes a signifier not only of the connection they once shared, but also of the level of isolation they now inhabit. Noelle Brada-Williams points out that food is used in Lahiri's collection as a metaphor for "home and the connection between people" (454). For Shoba and Shukumar, the significance of food is nothing less. Shukumar recognizes the immense amount of work that Shoba had once put into preparing meals and the ability she had to "throw together meals that appeared to have taken half a day to prepare" (7). Shoba used to spend hours preparing the ingredients for her complicated and involved recipes, and the results of this work could be found in "her labeled mason jars [that] lined the shelves of the kitchen" (7). After the loss of the baby and the breach in his connection to Shoba, Shukumar assumed the responsibilities of the kitchen, knowing that she "would eat a bowl of cereal for her dinner" if he did not cook (8). Even Shoba's cookbooks speak to the connection the husband and wife once had. Shukumar finds that "each of the recipes was dated, telling the first time they had eaten the dish together" (7). Their connection was founded on, among many other things, the food that they enjoyed together. Their isolation 
from one another even changes their eating habits: "for months now they' $\mathrm{d}$ served themselves from the stove, and he'd taken his plate into his study, letting the meal grow cold on his desk before shoving it into his mouth without pause, while Shoba took her plate into the living room and watched game shows, or proofread files with her arsenal of colored pencils at hand" (8). Their separation from one another leads them to live in the same house with hardly any interaction whatsoever.

Their separation is interrupted by the electrical work on their street; they are forced to eat together by candlelight. The darkness that they must inhabit while the electrical wiring is being repaired on their street offers them an hour a day where they have no excuse but to talk to each other. The darkness permits them both a sense of security: "something happened when the house was dark. They were able to talk to each other again" (19). On Shoba's prompts, they both open up and share secrets that they would not have ordinarily shared. The darkness allows this; they feel enveloped and shielded from the facial expressions and potentially painful responses the other might have. After four nights of admitting secrets to each other in the dark, Shoba and Shukumar make "love with a desperation they had forgotten" (19). The sense of security gleaned from the dark allows them to open up to each other on both emotional and physical levels. The one hour a day suggests that there is a hope for the reestablishment of connection after all, and Shukumar looks forward to their nightly confessionals.

On the fifth day of scheduled blackouts the couple receives a note saying the repairs were completed ahead of schedule and that there would be no more obligatory blackouts. After eating by candlelight anyway, Shoba tells Shukumar that she needs to tell him something and that she wants the light on so he can see her face. The darkness has gone, and Shoba returns to her separated state. She tells Shukumar that she has found her own apartment: "it sickened 
Shukumar, knowing that she had spent these past evenings preparing for a life without him. $\mathrm{He}$ was relieved and yet he was sickened. This was what she'd been trying to tell him for the past four evenings. This was the point of her game" (21). To complete the separation Shoba has made concrete by getting her own apartment, Shukumar tells Shoba that he held their baby before he was cremated. He also tells her the sex of the baby, a fact that "she had wanted to be a surprise" (21). Shukumar vowed he would never tell Shoba that their baby was a boy "because he still loved her then, and it was the one thing in her life that she had wanted to be a surprise" (22). His revealing of this knowledge in reaction to Shoba's announcement of her apartment shows that both of them have given up on their relationship. Having lost the chance of nurturing their baby, neither one has the capacity to nurture their relationship. After both of them admitted their final secrets, "they wept together, for the things they now knew" (22). They both yearn for the relationship they once enjoyed together but neither of them can understand how to make it right again.

Shoba's move to separate herself from her husband in fact refutes the idea that women need connection and men do not. If anything, this story shows that it is possible for women to be autonomous and for men to be dependent. A careful balance of these attributes in both sexes produces a successful relationship. Men need connection in the same ways and for the same reasons that women do. This realization is far from the generally accepted truth in North America. Traditionally, men are depicted as having no genuine need for relationship. Miller argues that "almost all of modern literature, philosophy, and commentary in other forms portrays men's lack of a sense of community" (Jordan, et al., 12). This common portrayal, as can be seen in this story, is far from the truth. Shukumar yearns for the connection with his wife even more than she does. In fact, she is the one who makes the most dramatic move towards autonomy by 
finding her own apartment and establishing her own separate life.

\section{Knowing the Stranger: "Interpreter of Maladies"}

Often it is not about wanting or needing to be dependent or independent, but about wanting to be in relationship with others and, again, to really comprehend the other; wanting to understand the other's feelings; wanting to contribute to the other; wanting the nature of the relationship to be one in which the other person(s) is engaged in this way. (Jordan, et al., 22, original emphasis)

In "Interpreter of Maladies," the main characters, Mr. Kapasi and Mrs. Das, both exhibit the need to be in a relationship that engages both parties, a factor missing from both their marriages. They both have romantic ideals about the type of relationship they want, although the reader is privy only to the thoughts of Mr. Kapasi. As in "A Temporary Matter," Lahiri focuses on the male point of view. The woman is again a mysterious figure of desire until the romantic illusion is crushed. Both Mr. Kapasi and Mrs. Das yearn to be in a relationship where they can understand and be understood by the other; however, since they are strangers, the connection they share is illusory. They are afforded a sense of security in the fact that they are strangers; it allows them a level of secrecy about their pasts, as does the dark for Shoba and Shukumar in "A Temporary Matter." The level of secrecy, though, prevents true connection.

Also, like “A Temporary Matter," this story shows that men sometimes need relationship as much if not more than the women. The protagonist, Mr. Kapasi, the Das's tour guide, and the female character, Mrs. Das, toy with the connection they think exists between them. They both yearn desperately for some form of connection. Mr. Kapasi yearns so much for a connection that he fantasizes about the extent to which his international relationship with Mrs. Das will escalate: She would write to him, asking about his days interpreting at the doctor's office, and he 
would respond eloquently, choosing only the most entertaining anecdotes, ones that would make her laugh out loud as she read them in her house in New Jersey. In time she would reveal the disappointment of her marriage, and he his. In this way their friendship would grow, and flourish. (55)

Mr. Kapasi craves connection with someone who appreciates his craft and takes a genuine interest in him. Mr. Kapasi grasps at the idealized connection he imagines he feels with Mrs. Das. His dissatisfaction with his own marriage leads him to relate to Mrs. Das because she, too, seems isolated from her family. Mrs. Das, likewise, is looking for any type of connection that shows promise of fulfilling the relational needs her family cannot satisfy.

When Mr. and Mrs. Das show interest in his occupation, Mr. Kapasi takes the interest to heart. He "knew that his wife had little regard for his career as an interpreter" and clings on to the fact that he is now in contact with people who see the importance in his career (53). This suggestion of connection is exaggerated in Mr. Kapasi's imagination. His fantasies about the relationship he wishes to have with Mrs. Das speak to his need for connection. When Mrs. Das asks for his address so she can send him a copy of a photograph, Mr. Kapasi fantasizes about their pen pal relationship and continually thinks about it, counting the days until he might expect the first letter. He writes his address with perfectionism and after he gives the slip back to Mrs. Das, he worries that "he had either misspelled his name, or accidentally reversed the numbers of his postal code. He dreaded the possibility of a lost letter, the photograph never reaching him, hovering somewhere in Orissa, close but ultimately unattainable" (56). His inability to control the parameters of the relationship worries him. Even the slip of paper bearing his writing is now out of his control, as it is tossed into Mrs. Das' bag without another thought.

Mrs. Das needs a connection that will allow her to open up to someone who will take a 
genuine interest in her plight without passing harsh judgment. She thinks Mr. Kapasi will provide this for her. At one of their tour stops at some monastic dwellings, Mrs. Das entreats Mr. Kapasi to stay with her in the car while the rest of her family go ahead to explore the caves. Mrs. Das opens up to Mr. Kapasi, hoping he can suggest a remedy for her feelings of intense guilt. She tells him that one of her three children, one of the boys, was not fathered by Mr. Das. The boy was conceived when she had a one-time affair with one of Mr. Das' friends. Mrs. Das admits that she is the only one who knows about this. Mr. Kapasi is at once flattered and disgusted that Mrs. Das would come to him and open up this way. Her confession sickens him: "Mr. Kapasi felt insulted that Mrs. Das should ask him to interpret her common, trivial secret" (66). Mrs. Das' affair speaks to her desperation for connection. She does not feel truly connected to her husband, which binds her to Mr. Kapasi because of his own dissatisfaction in marriage. Mrs. Das was so starved for a true connection in her marriage that the slightest touch from her husband's friend caused her to succumb to his physical wants.

Mrs. Das exposes herself to Mr. Kapasi when she divulges her son's paternal history. Her stay in India, which displaces her from her everyday life in America, makes her vulnerable and shows her need for connection. She latches onto Mr. Kapasi in the hopes that he will provide her with the relationship she needs but, to her disappointment, he is unable to provide that kind of relationship. Ultimately, he ends up pushing her away into the isolation he observed when he first met the Das family when he asks her, "Is it really pain you feel, Mrs. Das, or is it guilt?" (67). His dismissal of her confession, which makes her plight seem beneath him, shows how vulnerable she really is. She is deeply affected by his comment because it was not what she wanted to hear, and she immediately pulls away from him.

Mr. Kapasi's fantasy about his connection with Mrs. Das has been shattered because of 
her confession. The benefit of remaining strangers was that both parties could believe they have a connection they wished for without actually having to succumb to total honesty. For Mr. Kapasi, this situation was ideal and fulfilled his relational needs. Mrs. Das, however, wants to go further than that by indulging in complete and raw honesty. She soon finds out, by his scathing remarks, that Mr. Kapasi is looking for a connection that is not as honest as she would have liked. He is looking for a relationship that meets all of his meticulous ideals. He is not looking for a connection in which he feels he is merely a sounding board for problems; he needs a connection in which both parties are engaged and understood on his terms.

At the end of the story, the slip of paper on which Mr. Kapasi so diligently recorded his address on is lost. In a final flutter out of Mrs. Das' handbag, the paper signifies not only the connection that Mrs. Das and Mr. Kapasi thought they had but also Mr. Kapasi's dreams of having a deep bond with someone. The bond he felt with Mrs. Das, however, was only a fantasy. Much like Shukumar's idealistic picture of Shoba before the final revelation of her departure, Mr. Kapasi’s fantasy of Mrs. Das is shattered. June Jordan argues that "mutual empathy occurs when two people relate to each other in a context of interest in the other, emotional availability and responsiveness, cognitive appreciation of the wholeness of the other; the intent is to understand" (Jordan, et al., 89). This mutuality is not achieved, and so the expectations of the relationship on both sides are not met. Lahiri continually shows the difficulty of achieving such mutual empathy and "emotional availability" in human relationships. Loss and disappointment often cause her characters to close up or shut down. They are less involved in a real relationship than a fantasized one.

\section{Overcoming Illusion: "Sexy"}

A subcategory of women who endure some pain in order to gain self-esteem is women in 
relationships with married men. (Caplan, The Myth of Women's Masochism 88).

The opening scene of the story "Sexy" serves as the backdrop for much of the immediate action between Miranda, the protagonist, and her lover, Dev. Miranda's coworker, Laxmi, has a cousin whose husband has left her because he met a beautiful, young woman on a flight. Showcasing a broken connection between husband and wife, the opening scene sets the tone for the rest of the story. Miranda is a lonely, young, working woman who is fixated on Dev, a dark, passionate, married man, whom she meets at a department store counter. Dev is buying products for his wife, as she is leaving for India for a few weeks. Miranda attaches herself to Dev, who shows her unaccustomed attention. Miranda, who is so eager for relationship that she jumps at any chance to be connected, becomes Dev's mistress. While Miranda knows that her relationship with Dev is wrong, she gains a sense of self-worth from it, as Paula J. Caplan suggests above about women tolerating pain in relationships with married men to gain selfesteem.

"Sexy," unlike the other two stories discussed here, features a female protagonist and a female narrative perspective. Miranda struggles with her loneliness and, as a result, is eager to foster a connection with Dev. This story juxtaposes the differences between male and female social conditioning. Janet L. Surrey explains the difference between boys and girls as they grow up in American society:

For boys, the emphasis on early emotional separation and the forming of an identity through the assertion of difference foster a basic relational stance of disconnections and disidentification. Girls, then, develop the expectation that they can facilitate the growth of a sense of self through psychological connection and expect that the mutual sharing of experience will lead to psychological growth. (Jordan, et al., 56) 
Dev and Miranda both match Surrey's description through their opposing relational involvement. Dev is largely disconnected from Miranda in that he keeps the relationship, from the very beginning, at a physical level. Miranda, on the other hand, yearns for the relationship to mean more than that.

Dev is gifted in that he has an ability to make Miranda feel truly connected to him. He leaves messages on her machine so that "she could hear his voice as soon as she walked through the door" (88). Dev wants her to need him and to feel she can depend on him . He wants her to connect to him so that she is committed to him through their relationship. Her loneliness makes her latch onto Dev, showing her desperation for connection. She needs a relationship because, without relationship, she has no way to define herself in her new home in Boston. While she admittedly chose to move to Boston to get away from everyone and everything she knew in Michigan, she is by herself (89). Alone, there is no way Miranda can define herself in her new space. Dev gives her the connection she needs to start to form a sense of self in her new home. He tells her that he understands her position: "I know what it's like to be lonely" (89). It is this statement that pulls Miranda to him: "at that moment Miranda felt that he understood her -understood how she felt some nights on the T, after seeing a movie on her own, or going to a bookstore to read magazines, or having drinks with Laxmi, who always had to meet her husband at Alewife station in an hour or two" (89). Finally, Miranda is able to connect with someone who seems to understand her. Laxmi, her coworker, friend, and only other contact in the city, is often preoccupied with her husband and, at the moment, is totally preoccupied with her cousin's looming divorce. She does not offer Miranda the genuine connection she yearns for, so Miranda jumps at the possibility of a relationship with Dev.

On one occasion Dev takes Miranda to the Mapparium at the Christian Science Center 
where on the ceiling of a globe-shaped building, the map of the world is illuminated in stainedglass. When one stands inside of the building, it is as if one is standing inside of the world, looking up through the bottom of the continents. During this visit, Dev tells Miranda that the quality of acoustics in the Mapparium would allow them to whisper to each other from opposite ends of the room and hear each other perfectly (91). When the two of them are at opposite ends of the walkway, Dev whispers "You're sexy" to Miranda, and she hears the words "so clearly that she felt them under her skin, under her winter coat, so near and full of warmth that she felt herself go hot" (91). The illusion of intimacy, much like the illusion of connection between Mrs. Das and Mr. Kapasi in "Interpreter of Maladies," allows Miranda to feel as though she has truly connected to someone, even though it is a purely physical connection. Dev's choice of words, however, speaks to his focus on the physical or sexual and his lack of a need for a truly intimate relationship. Instead of telling her that he felt love for her or that she was beautiful, he chooses to tell her she is sexy. Dev has caught Miranda in an illusory web of connection in which she cannot distinguish real connection from lust. Just as Shukumar fantasizes a growing closeness with Shoba in the dark in "A Temporary Matter," Miranda believes in an unreal bond with Dev. For days after this visit to the Mapparium, Miranda dreams about the experience and the fact that Dev called her sexy: "it was the first time a man had called her sexy, and when she closed her eyes she could still feel his whisper drifting through her body, under her skin" (92). Dev successfully flatters Miranda. He has made her feel wanted and needed. He has also, however, taken advantage of her naiveté and her need for connection. By whispering those two little words, Dev is able to bring Miranda closer to him while still keeping the understanding that he is a married man and can be in this relationship with a mistress without worrying about emotional connection. By foregoing the emotional connection, Dev is able to guard himself 
against true connection with Miranda. Avoiding a true emotional connection keeps his interactions with Miranda at a superficial level and this allows him to feel less guilty about his infidelity. Miranda cannot distinguish between an emotional relationship and a sexual connection and is so desperate for any type of connection at all that she is simply happy to be connected.

Unfortunately, Miranda's desperation means that she takes her connection with Dev more seriously than he does. She shows this when she goes shopping while he is at the airport, picking his wife up from her trip to India. Miranda buys lingerie and a stunning silver cocktail dress that she pictures wearing out to dinner with Dev at a fine restaurant (93). Critic Jean Wyatt states that "one identifies with what one wants to be, and what one wants to be is inevitably influenced by cultural definitions of desirability" (5). Miranda, by purchasing the dress, shows that she has preconceived notions about what is sexy. Since Dev called her sexy, Miranda tries to fit into the societal parameters of what is considered sexy. She also links those notions to the level of relationship she wants with Dev, fantasizing about the possibility for romance.

Once his wife comes back from India, Dev only sees Miranda on Sundays, when he uses the excuse of coming into Boston to run along the Charles River. The first Sunday, Miranda dresses up in her newly-bought lingerie but soon realizes that it is of little consequence: "The first Sunday she opened the door in the knee-length robe, but Dev didn't even notice; he carried her over to the bad, wearing sweatpants and sneakers, and entered her without a word" (93). Dev's approach to their relationship is all business: he wants sex, and that is what he is intends to get. Miranda quickly catches on but at first she does nothing to correct or stop his womanizing techniques. In fact, she adjusts for the following Sunday rendezvous:

So the next Sunday she didn't bother. She wore jeans. She kept the lingerie at the back 
of a drawer, behind her socks and everyday underwear. The silver cocktail dress hung in her closet, the tag dangling from the seam. Often, in the morning, the dress would be in a heap on the floor; the chain straps always slipped off the metal hanger. (93)

The dress, a symbol of the relationship she thinks she has with Dev, is stuck in her closet where it refuses to stay on its hanger. Similarly, Miranda's relationship with Dev is not what she ultimately yearns for and she has no way of making the connection with Dev fulfill her relational needs.

Her connection to the other extra-marital affair of the story soon has a direct effect on Miranda's life and on her realizations about her relationship with Dev. Laxmi, in an attempt to comfort her cousin whose husband left her by taking her to a day spa, asks Miranda to watch her cousin's son for the day. When Rohin is with her, it is quite clear to see how easily Miranda is ordered about. She puts up no fight with Rohin and does whatever the seven year-old tells her: she gives him coffee, albeit very light and sweet; she rattles off countries so he may practice repeating their capitals; she draws for him; and she makes no protest when he disappears and finds him going through her medicine cabinet. The last thing she does for him is put on the silver dress that she bought when she thought her relationship with Dev was something more than sexual. When Rohin asks, or rather orders, Miranda to put on the dress, she realizes that 'there was no reason to put it on. Apart from the fitting room at Filene's she had never worn it, and as long as she was with Dev she knew she never would" (105). Miranda knows her relationship with Dev is not genuine. She knows their connection is purely sexual and it will not meet her relational needs. However, because she is lonely and desperate for connection, Miranda holds onto her illusory relationship with Dev for as long as possible.

Rohin, when he sees Miranda in the silver dress, tells her that she is sexy. Recalling the 
day in the Mapparium when Dev had told her the same thing, she remembers thinking that she understood what Dev was trying to tell her. She thought the words meant more than just sex. Now, though, she realizes that Dev's words were more superficial than she first imagined. When pressed to tell her what he thinks it means when someone is called sexy, Rohin answers that "it means loving someone you don't know" (107). Miranda knows that you cannot truly love someone without knowing them. That kind of genuine relationship is what she really wanted: a relationship in which she and her partner grew to know and love each other. After her day with Rohin, Miranda knows she will never be able to reach the level she needs with Dev.

After her time with Rohin, Miranda slowly sees less and less of Dev. It is not necessarily a planned break, but it is certainly not a break that either tries to rescue. After three weeks, Dev does not call Miranda and she goes for a walk through the city. She finds the Mapparium closed so "she bought a cup of coffee nearby and sat on one of the benches in the plaza outside the church, gazing at its giant pillars and its massive dome, and at the clear-blue sky spread over the city" (110). These last lines of the story denote a sense of hope for Miranda. The openness of the blue sky portrays Miranda's sense of not being so alone in the world. She has recognized the difference between superficial and real connection. She knows that she needs real connection where both people are invested emotionally, not just physically. Miranda's connection with Dev, although it was painful because of its lack of depth and because of her shattered romantic ideals, causes her to recognize her relational needs. Her affair with Dev boosts her self-esteem in that she is confident enough to assert her needs. This, in a way, makes the pain of the broken affair worth the heartache and confusion. 


\section{Mary Gaitskill's Because They Wanted To}

Mary Gaitskill's characters in Because They Wanted To search for ways to belong to community while sustaining individuality in environments that isolate them and from which they simultaneously shrink away. The use of eroticism and sex sets this collection apart from the others discussed here as Gaitskill's characters search for emotional connection as well as protection of their emotional selves through the exploration of sexual fantasies. Engagement in sexual fantasy allows the characters to feel connected, even though their degrading or humiliating fantasies prevent genuine interaction. The protagonists are concerned with hiding their true selves from others and from themselves through sexual fantasy. Their pasts, which often include abuse, pain, and loss, make them wary of what their true selves may reveal. Their emotions about those experiences, having been repressed, are in some ways unstable and, more importantly, uncontrollable. Thus, participation in sexual fantasy enables them not only unrealistic connection with others, which makes them feel truly connected, but also allows them to avoid dealing with their true emotions.

Gaitskill's characters' need for sexual connection speaks to the role that past trauma plays in their adult lives. Their pasts, which often involve some kind of sexual molestation, lead them into an adult life where true connection is derailed by sexual fantasy. The sexual fantasies allow them to maintain a sense of secrecy in their interactions. This is similar to the role of fantasy in Lahiri's collection, where the fantasies invoke a romantic ideal of the other and allow each participant a level of mysterious interaction. While Lahiri's characters focus on pursuing connection through romantic fantasy and idealization, Gaitskill's characters do so through sexual role-playing and behavior.

Many protagonists in this collection divulge their past at some point in the story, which 
often involves leaving home during the mid-teen years. The separation from home is often accompanied by sexual or emotional abuse that spurred the initial separation. The protagonists who are exposed to this kind of abuse often look for similar experiences in their adult lives because it is the familiar and only kind of connection they have experienced. Judith Herman argues that "trauma impels people both to withdraw from close relationships and to seek them desperately" (56). The trauma Gaitskill's protagonists have experienced prevents them from connecting authentically yet they desperately seek for ways to feel authentic connection. Gaitskill's protagonists, because of their troubled pasts, equate sex with kindness or connection. As a result, if they are shown any attention they automatically assume a sexual relationship is desired. Emotional needs are hardly ever considered as physical desire is paramount.

The protagonists rely on erotic experiences to define themselves, even though those experiences deny them true definition. The emotional pain experienced as a result of their sexual fantasy lives is sought because it allows the protagonist to feel closer both to the person inflicting the pain and to a deeper level of feeling, albeit unreal feeling, about herself. By allowing a person to inflict both physical and emotional pain, each protagonist moves the pressure of defining self onto the other, even though the superficiality of the sadomasochistic dynamic prevents true connection. Barbara Schapiro states that "Gaitskill's fiction suggests that the enactment of sadomasochistic fantasy, rooted in trauma, is ultimately futile, for it can never lead to the nourishment, the genuine recognition of self and other that is unconsciously sought" ("Trauma and Sadomasochistic Narrative" 48). The fantasies offer an illusory connection both to the other and to the true emotional self.

The contradictory tendencies with which the protagonists strive for connection make it even more difficult for them to maintain genuine relationships with others. Their simultaneous 
need for and fear of true emotional connection unbalances the protagonists in their search for relationship. The protagonist's past trauma causes her to "preserve the boundary between inside and outside, and the continuous threat of its dissolution can come to dominate one's life" (Schapiro, "Trauma and Sadomasochistic Narrative" 40). In an effort to protect her true self, then, the protagonist maintains boundaries that separate the individual from the other, preventing genuine connection.

These dynamics are particularly present in the stories "The Blanket," "The Dentist," and “The Wrong Thing." Even though all of Gaitskill's stories speak of the struggle to find a place for individuality within community, the last cluster of stories entitled "The Wrong Thing" features a character who finally allows herself to connect to others, in this case a group of women, on a level that goes deeper than sexual fantasy.

\section{Power Through Connection: "The Blanket"}

One of women's particular sources of strength [is] the power to empower others, that is, to participate in interaction in such a way that one simultaneously enhances the power of the other and one's own power. (Jordan, et al., 164, original emphasis)

Valerie, the protagonist in "The Blanket," is a mature woman who gets caught up with Michael, a much younger and seemingly immature lover. This story shows, as Janet L. Surrey suggests above, that a woman has the ability not only to find strength in herself through relationship but also to strengthen others through connection. Valerie's emotional vulnerability causes her to rely on sexual fantasy. She is afraid of her own feelings because of her past rape experience and she avoids truly connecting to Michael. Valerie wants desperately to embrace the connection she feels with Michael even though she initiates the sexual fantasy life that shields their true selves. The sexual fantasy life she initiates with him enables her to feel she 
connects to him. On the contrary, their involvement in sexual fantasies denies both characters true connection. When Valerie allows herself to genuinely connect to Michael at last, she finds the ability to empower both herself and her lover in their relational interactions.

Socially dictated gender roles are prevalent in this story, and both Valerie and Michael are drawn in by those prescribed roles. Michael, on his second visit to Valerie's apartment, brings her bags of fruit and exclaims that he is a "provider" (89). As a man, he feels he must provide for the woman. Valerie knows that he “couldn't actually provide for her, but she didn't need him to do that" and is flattered by his immature but chivalrous nature (89). Valerie, in turn, takes on the prescribed feminine role by allowing Michael to believe he can provide for her. She is self-sufficient but still finds his gesture to be "both generous and slightly inept, which she found sweeter than generosity straight" (89). By engaging in roles that are predetermined, they try to fulfill certain criteria for relationship. In the course of their relationship, though, they question those roles by utilizing sexual fantasy. They establish a life that involves them deeply on a traditional but unrealistic level, as well as on a level that employs sexual fantasy to hide their true selves.

At first, Valerie ignores the level of connection she feels with Michael. She makes multiple excuses to her friend as to why their relationship could never work: "It's just sex, really; I mean, he's too young for us to actually get involved. But the enthusiasm of him -- I mean, he's just right there" (91). When her friend challenges this statement by pointing out that Valerie likes it when Michael calls her his girlfriend, Valerie says that she does like it but "it's like another version of the slutty-teenager fantasy. It's real, but only in the erotic realm. I mean, we have feelings for each other, but they can't be permanent" (91). While she acknowledges her feelings for Michael, Valerie cannot allow herself to acknowledge the level of genuine 
connection that seems to exist between them. Their sexual life, however, affects Valerie so intensely that she becomes strongly connected to Michael. When Michael goes away with his band, she finds "one of his sweaty T-shirts balled up at the bottom of her bed and found she had to listen to loud music while she paced around with the shirt pressed to her cheek" (92). She cannot help but be attached to Michael, and yet for a while she refuses to recognize how strongly she is connected to him. She keeps Michael at a distance through sexual fantasy, and does not allow herself to genuinely open up to him.

The fantasy life that Michael and Valerie construct allows them to maintain mystery and secrecy from one another and from themselves. By playing roles outside of their true emotional selves, they do not have to be honest with one another. They create many different role-playing situations:

She would be a slutty teenager who's secretly hoping for love, and he would be the smug prick who exploits her. He would be the coarse little gym teacher trying to persuade the svelte English teacher to let him go down on her after the PTA cocktail party. She would be a rude girl with no panties flaunting herself before an anxious student in the library.

The various sexual fantasies allow for exploration of different desires. The fantasies also allow Valerie and Michael to retreat from honesty into the safe haven of make believe.

The mixture of sexual aggression in the fantasies and the aching need for genuine connection make for poignant sexual experiences for both Valerie and Michael. Their intense sexual experiences are peppered with moments where they seem to let their guards down and truly connect. While acting out one of their fantasy scenes, for instance, "aggression surged between them in bursts, but he'd paused to bend and press his cheek against her thigh" (91). In 
the high instant of sexual interaction, Michael and Valerie have brief moments where their connection is genuine. Even so, both pretend they do not recognize the connection and continue with the fantasy, shirking from the level of vulnerability they need to expose for true connection.

Ironically, the fantasy life that at first keeps the two from truly connecting leads to their authentic bond. As is the case with many protagonists in Gaitskill's collection, Valerie divulges her past in an attempt to explain herself and connect with Michael on a level deeper than sexual intimacy. Valerie, yearning for genuine connection, attempts to move beyond the sexual front she has erected between herself and Michael by sharing her past traumatic rape experience. She tells him about her experience of being raped and he misunderstands it as a prompt for another fantasy. He takes her for a drive and sets up a rape fantasy (inspired by Valerie's experience) by stopping on a dirt road. Valerie, in reaction, takes a defensive stance and reverts into silence and isolation. Understandably, Valerie is hurt by Michael's misinterpretation because she has revealed her vulnerability and he has taken advantage of it. Valerie has taken a significant step towards making her relationship with Michael genuine. When he misinterprets her story as a prompt for another fantasy, Valerie reverts back into her isolated self. The lack of communication about her genuine attempt for connection pushes them apart.

This scene, through frightening for Valerie, eventually gives them the opportunity to open up to each other. Michael obeys Valerie's wishes after the intense misunderstanding and drives her home. In front of her house, the two fight and Michael says that if she does not say something nice to him soon, the situation "is going to be really bad" (99). In response to this plea for peace, Valerie tells him that she loves him and finally gives into the connection she has felt with Michael from the beginning. The intensity of the sexual fantasy life they share has come to a head. It can no longer protect them from the vulnerability of true connection. Once 
Valerie feels as though her connection with Michael is threatened, she quickly tries to mend the break by exposing herself and attempting true emotional interaction.

The final scene of the story shows Michael and Valerie reconciled. Since Michael is going away for a show with his band the next day and will not be able to see Valerie for a week, he insists on staying the night with her. She finally gives in on the condition that he sleep fullyclothed outside of the sheets. Michael keeps his promise by sleeping on top of the blankets to prove to her that he can respect her wishes. When Valerie wakes in the middle of the night to find him shivering on top of the covers, she asks him to join her in bed. At first he refuses, arguing that he made a promise he intends to keep. Valerie insists Michael join her under the blanket and he finally does. It is a caring, maternal move Valerie makes that further cements her deep connection with Michael. She shows she truly cares for his well-being. Michael's vulnerability, as he shivers on top of the sheets, invites Valerie to act maternally and take care of him. Even though it has taken a frightening episode for Valerie and Michael to reach this point, there is hope that they will be able to nurture a genuine relationship because both were able to gather the courage to share their vulnerability. Their interaction has developed to the point where both are empowered in their connection. This empowerment allows them to connect to each other without having to hide under the sexual fantasy façade.

\section{Balancing Sexuality: "The Dentist"}

Adult sexuality ideally balances the relational need for recognizing the separate subjectivity of the other and the erotic need for idealizing/fantasizing/objectifying the other. (Juhasz 20)

“The Dentist" introduces Jill, a young woman who is desperate for relationship but who struggles to procure and maintain any type of connection. Jill becomes obsessed with her dentist, George, and with her ideals of the type of relationship they could have. Jill struggles to 
balance the "separate subjectivity" of George with her "erotic need" to sexually objectify him. Again in this story, the primary mode of relationship is through sexual fantasy and innuendo. Like Valerie in "The Blanket," Jill hides behind a sexual façade that showcases sadomasochistic roles.

George, unlike Jill, is a very quiet and meek man. He is afraid of any type of real connection and prefers his autonomy. He is put off by Jill's advances and quickly tries to separate himself from her, even though she tries to stay connected to him. He is a very simple person; as he puts it, "I'm bland and I have a low level of emotional vibrancy and I like it that way!" (166). Even though he argues he is a simple man, there is a possibility George may actually be a deeply sexual person: he studied lesbianism among strippers and he once worked as a cameraman for a low-grade porn company. This information intrigues Jill and she tries harder to get him to interact with her. The intensity with which Jill approaches him is off-putting and creates fear in George. The two push and pull each other as they negotiate their connection.

Jill and George initially meet when Jill has to get her fourth wisdom tooth removed. At first, throughout the course of their meetings, Jill does not sense any connection with the dentist. As complications from the extraction ensue, however, she sees him for more pain medication and vents her frustrations on him: her computer has broken, and since she is a commissioned writer, not only is she in excruciating pain from the dental surgery, but she cannot work. As a gesture of kindness and good will, George offers her his laptop so she can get some work done and find some distraction from the pain. It is this act of random kindness and generosity, like Michael's generosity in "The Blanket," that attracts Jill. Jill's infatuation blossoms when she receives these acts of kindness along with his offer to help her with the laptop at any time of the day. She reads his offer to teach her how to use his laptop as an implied attempt at connection: "He wants to be 
my friend, she thought. Probably he's not thinking sex; he's not the type. I'll just have to be friendly with him, which is a pain, but if I can type that article, the activity will make me less hysterical" (140). Jill recognizes that George does not seem to be the sexual type. Regardless, she is drawn to his easygoing manner because it is the opposite of her own tight anxiety. She immediately thinks of sex because that is her comfort zone and is the only way she knows how to connect.

Sex, for Jill, is an integral part of any connection. Even the dentist, who is so unassumingly asexual, is transformed into a sexual sadist in her fantasies. Even though she can never actually achieve sexual satisfaction with George in her fantasies, Jill continues to make the attempt. Jill's fantasies never actually develop to the point where she visualizes having sex with George. On the contrary, she tries her best to bring that aspect into her frame of vision but is unsuccessful. His normalcy attracts Jill, as in one instance when she calls him hoping for some instruction on how to work the laptop he has lent her: "The banality, the politeness, and the harmless hint of command were all accentuated by the abstracted context and took interesting forms in her imagination. Happily, she visualized all kinds of things he might want to do to her" (145). His unfeeling tone of voice and his motorized commands on how to operate the laptop incites her sexual curiosity. His easygoing manner balances out her own hysteria.

Jill works extremely hard to connect with George, even though he resists every advance she makes. A connection with him soon becomes her goal. Jean Baker Miller says that, women's sense of self becomes very much organized around being able to make and then maintain affiliations and relationships. Eventually, for many women the threat of disruption of connections is perceived not as just a loss of relationship but as something closer to a total loss of self. (83) 
Jill's sense of self is threatened because George resists her. Her struggle to connect with him becomes a power issue for Jill: she needs to have control over her interactions with others as that allows her control over her sexuality. As George continually avoids Jill's sexual advances, Jill becomes deeply affected by his responses to her. Even though she shares and makes light of her confusing experiences with her close friends, Jill becomes even more infatuated with George because he resists her sexual advances. Even so, Jill cannot escape the comfort zone that she has inhabited for years; she cannot escape the conditioned responses of a sexually-based life. She will not let go of her fantasy life in order to seek true connection with George, even though that connection is what she truly yearns for.

Due to her confusion about her connection with George, Jill starts to see a therapist. Jill complains to her therapist that "he's being apparently nice to me, and then when I respond he pulls away" (154). Jill responds to George's kindness by offering sex. She does not realize that her sexual responses to George's nonsexual actions push him away rather then pull him closer. The therapist responds to her confused statement, saying that,

"in the [North American] culture," many people had not been confirmed enough so that they could extend themselves to other people with "the full capacity of their being," because "the culture" was in a state of spiritual lassitude that enforced a level of blandness as the only acceptable way of relating. Underneath, she continued, was a great longing for free, unconvoluted expression, in which beings could be fully present with one another. (154-55)

Living in the American culture, George has not found a way to open up to others. Rather, his blandness is accepted by the society in which he lives. Jill, on the other hand, constantly feels the need to reach out to make connections. When her therapist tells her that many people may 
harbor a need for free expression, Jill feels even more strongly about making her connection with George work, and believes that deep down he truly wants to connect. Paula J. Caplan argues that North American males are usually taught that they do not need to express many of their feelings, but females are encouraged to be more expressive and to learn how to do this. Thus, male-female relationships presumably bring together some kind of ideal match: one who can and one who cannot, or needs not show strong feelings. (ㄹetween Women 139, original emphasis)

George and Jill both fit these parameters. He is guarded and shows hardly any emotion. Jill tries to bring him out of his shell by showing herself to him. She tries to fit into the traditional stereotype of a North American woman who is concerned with his feelings and tries desperately to show her concern for him. Her unorthodox sexual tendencies that show through this attempt, though, scare George and push him further away.

When Jill realizes that George is pulling away from her rather than coming closer, she tries even harder to connect to him which, in turn, scares him away more. Jill acts even more intensely and shows desperation when he refuses to meet her relational expectations. Jean Baker Miller says that "people are often convinced that they need to relate to the world and people in it in a certain fixed manner, and they may react forcefully if they cannot bring about the desired situation or relationship" (37). Jill, because of her past and because of the sexual life she leads, feels that the only way to have a successful relationship is by basing it on sexual experiences. When George refuses to comply to what she is convinced she needs, Jill acts with even more urgency to try to connect to him because his denial of her threatens her sense of self. One technique she uses is telling George about her childhood molestation. She tries to bring him closer by doing so. 
Jill's past constantly and repeatedly effects everything she says and does. When she was five, Jill was molested and she reveals this information to George in an effort to engage him. This information, unfortunately, pushes him away even more. She makes matters worse when she tells him that she was reminded of the repressed trauma when she was ten: she was watching a cartoon that had a character with lips that were similar to the lips of her molester. After making the connection, Jill admits that she got excited and had to masturbate, all the while thinking about the molestation (158). Echoing Valerie in "The Blanket," Jill divulges this painful information to George in an effort to reveal her vulnerable side and connect to him. Unlike "The Blanket" where Valerie and Michael are eventually able to connect, though, Jill's disclosure of her past works against her and only pushes George more.

Jill, in a masochistic way, relates the mystery of her sexual abuse to her connection with the dentist. By connecting the past with the present, she relives the molestation and all of the humiliation it caused. Jill wants to relive the emotional pain and humiliation of her molestation because it allows her to connect to genuine feelings deep within herself. George's mysterious nature attracts Jill; his stand-offish behavior only pulls her closer. George, by resisting and showing no interest in Jill's sexual advances, suggests to Jill a connection that goes beyond the sexual. This kind of connection is what Jill ultimately wants but she cannot escape the sexual tendencies that prevent her from true connection. Even though George's past is peppered with sexual experiences that he is detached from, he does not need to focus on the sexual in his daily interactions with others. Jill, on the other hand, does because that is the only connection she has been able to hold onto. Even though she remembers her molestation, she does not fully understand it because she repressed it for five years and, even so, cannot explain why the memory of such trauma excited her. The mystery of George, who is inherently a very simple 
man, lies in the fact that he resists making any type of real connection to her. Unlike the stereotypical male who should make every effort to have sexual relations, at any expense, George resists that type of connection. Jill is attracted to this sense of mystery and the sexual illusion George offers her attracts her further.

In a further attempt to connect, Jill tells George about a television show one of her friends told her about. In this show, victims and the families of victims are able to confront the criminals who victimized them and ask them why they committed such horrible crimes as rape and murder (144). The masochistic act of confronting the person who has caused so much pain and anguish attracts Jill. The pain relived by confronting the abuser allows the victim to connect to the deep emotions that have been deeply hidden. In a similar way, Jill yearns to disassemble the boundaries between her and her trauma in an effort to deal with the painful emotions left by the molestation. Barbara Schapiro says the masochistic act of wanting to confront one's victimizer is "an attempt to break through to the other, to recognize and be recognized in all one's shameful, hidden pain" ("Trauma and Sadomasochistic Narrative" 45). Jill yearns to express her pain but her sexual tendencies prevent her from doing so because such an act would require an understanding of her true self.

Jill also tries to connect to George through another sexual avenue. She finds out that he did his undergraduate thesis on lesbianism among strippers in Scranton, Pennsylvania. Thinking this may be a way to connect to his sexual being, Jill unsuccessfully tries to push the conversation further. When she asks what kind of show the strippers performed, George informs her that he never watched the strippers, but only interviewed them (145). This piques her interest because she cannot understand how a man can resist the temptation to watch a woman take her clothes off, especially if he is heterosexual. She also comes to find out that he once worked as a 
cameraman for a low-grade pornography company, although he says that he was "disgusted by the way the women were treated" (146). When he invites her to a piercing exhibit, Jill is surprised by this sadistic interest, but defers saying she would rather see a movie (148). Soon after he asks her if she wants to go to the piecing exhibit, Jill has a dream where the dentist pierces her genitals with a needle. Jill believes that "there is nothing like physical pain for enlarging and enhancing free-floating emotional pain" (139). For her, the piercing fantasy allows her to connect to her emotional needs through physical pain. The dentist's apparent sadistic interests attract Jill and she clings to the sexual in an attempt to connect to George. She tries to use George's past to connect to him but he resists.

Their relationship has been faltering all along but it comes to a head when Jill visits George at his office as he is closing. Jill tries to have a conversation with him but he gets flustered and she realizes that he is "apoplectic with fear" (166). She realizes how much she has scared him with her sexual innuendoes and, in the end, feels terrible for it. When George finally tells Jill that he does not want relationship with anyone, her fantasies are shattered. She has denied this fact since she met him, assuming that his kindness was a way to connect with her sexually.

Even so, she uses the experience with George to make new connections. At a dinner party hosted by a close friend Jill relays her encounters with the dentist. She tells her story as a light-hearted occurrence that did not mean anything to her even though she has a sense of reverence for George. She keeps her true feelings about him revealed. She tells one of the guests at a dinner party, in response to her comment that maybe if Jill was able to get George "into a sling, he'd be fine," that, "No, I don't think he'd actually ever get into a sling, whether he wanted to or not. I think he'd just keep getting into slinglike positions in inappropriate 
situations" (167). Jill recognizes that she has described herself and that she has been unable to balance the "relational need for recognizing the separate subjectivity of the other and the erotic need for idealizing/fantasizing/objectifying the other" (Juhasz 20). In her attempts to connect with George, Jill has not been able to balance her erotic need with his individuality. This inability causes Jill, at the end, to revert back to her comfortable state of sexuality in which she can hide her true self and superficially connect to others.

George symbolizes a relationship that Jill yearns for; one that is not based solely on sex. She will never be able to obtain this type of relationship because of her past and because of the role of sex in her life. Nevertheless, she uses her experiences with George to start conversation with others. She has, of course, reverted back to her state of isolation in that she does not divulge her true feelings about George. Her comfort in this guarded state, although it is to her detriment, predicts her lonely stability in isolation and confirms her inability to connect.

Female Love and Strength: "The Wrong Thing"

Any close relationship between two women has the potential for intense, uncontrolled emotionality and contact with the deep recesses of the unconscious. Thus, what they are afraid of is encountering their own strongest feelings, wishes, and terrors. (Caplan, Between Women 140)

Gaitskill's whole collection shows women who struggle to find their niche in the world in relation to others through sexuality and eroticism. "The Wrong Thing," the final installment in the collection, depicts the promise of the ability to emanate power from the marginalized site not just of women, but women who are open about their need for connection and their sexuality, whether they are bisexual, homosexual, or heterosexual. Gaitskill's “The Wrong Thing” shows women's need for relationship and the recognition of that need. Being without connection in this 
story is more threatening than being attached, even if it is to the wrong person. Susan, the protagonist, tells her story as she wanders through sexual relationships, finally coming to the realization of a serene happiness in the company of female friends. The journey to this realization is wrought with hardship for Susan as she uses sexual fantasy to skirt around dealing with her true emotional being. Susan, a college poetry professor, is unsatisfied with her life and yearns to find satisfaction. In the opening lines, for example, she separates herself from the stereotypical and expected conversation of daily interaction: "Today the clerk in the fancy deli next door asked me how I was, and I said, 'I have deep longings that will never be satisfied'" (191). Her brutal honesty speaks to the underlying despair she feels that typifies many of Gaitskill's characters.

"The Wrong Thing" is a short story cycle in and of itself. Made up of four sub-stories, "Turgor," "Respect," "Processing," and "Stuff," the cycle focuses on the same characters, settings, and thematic tensions. While each installment has the capacity to be independent of the others because each has a strong opening, middle, and end, its inclusion in the bigger cycle only strengthens its context. The cycle is so complete that Susan actually connects at the end with one of the first characters introduced in the cycle. This allows the reader to experience the underlying connection among the stories intensely because the connections are less subtle than in the rest of the collection. By the same token, the interaction between these stories speaks to the deep interaction among the multiple relationships that engage Susan. Carol Gilligan argues that women have the ability to "illuminat[e] life as a web rather than a succession of relationships" (48). Susan's web of relationships showcases her need for attachment over autonomy.

The four sub-stories show the web of connection in which Susan is involved. "Turgor" introduces Susan and depicts her attendance at a party and ensuing experience with Frederick, 
the young man who has a considerable effect on her sexually and emotionally. "Respect" also develops the relationship between Susan and Frederick, although this story shows Susan trying to connect to him on a level deeper than the purely sexual relationship they explore in "Turgor." It is in this story that Susan is hurt by Frederick when her idealized fantasies about him and the connection they have together are crushed. "Processing" introduces Erin, the woman with whom Susan eventually reaches a deep and genuine level of relationship. In the final story of the sequence, entitled "Stuff," the fourth and final main character, Kenneth, is introduced. Susan's relationship with Kenneth never blossoms into a sexual one and this allows her to explore a platonic connection that is void of sexual pressure.

Like many of Gaitskill's characters, Susan is strangely tense and anxious in her personal relationships. She struggles to reach the point in any given relationship where she and her partner can be honest and true to one another, even though she hinders that process by hiding behind a sexual front. She hides behind sexual fantasy and erotic role-playing, like Gaitskill's other characters, in order to further alienate herself from the person with whom she interacts, even though she yearns to genuinely connect. She asks Erin, for example, if they can make love as honestly as possible. Both women tell each other that they have a long history of engaging in sexual relationships that involve sadomasochistic sex and that they are looking for a relationship that will offer them a deeper level of connection. That being said, neither of them are emotionally open enough to connect authentically. They try to engage on a genuine level but ultimately find it impossible and revert back to their hidden selves by giving into the familiar urge to engage in role-playing sex. It is not until the end of the cycle, at the end of "Stuff," that both women have found that relationship does not necessarily have to be based on sex to be successful. 
At the beginning of "Turgor," Susan attends a birthday party for a "self-described pro-sex feminist who had created a public niche for herself as a pornographer and talk-show guest" (192). Here, Susan meets Frederick. Susan automatically assumes that she will not be able to meet the expectations she reads in Frederick's look: "it was a look of stunted idealism, a shallow romanticism that could only be disappointed at -- even appalled by -- the substance that lurks under any fancy façade, including mine" (192). Susan has adapted herself to believe that anybody who gets to know her is going to be disappointed by her true self. This is another reason why she hides behind sexual experiences; the role playing and experimenting allows her to get deeply involved in something that is completely separate from herself. She is able to hide from her own feelings and protect those feelings from others. Susan also breezes by Erin in the opening scene when Erin takes a picture of her and Frederick. While the two women do not actually have any concrete contact, there is a subtle attraction that Susan notices: "[Erin] was drunk, and she gave off a peculiar chemical shimmer that was sweet and lurid and had a seductive little suck to it" (193). This subtle connection draws the two women together at a later party.

Turning her attention back to Frederick, Susan leaves the party with him. In the cab ride to her apartment, Susan notices an "artificial closeness" that makes her "sense acutely how alone [she] would feel when [she] said goodnight and entered the long, dark hallway of [her] apartment" (193-94). Even though she recognizes the superficiality of their connection, Susan grasps at it because to be without connection only emphasizes her loneliness. She invites Frederick in and attempts to foster genuine connection with him. Susan reveals personal facts while engaging in foreplay to try to move past the artificiality. She automatically slips into the sadomasochistic role that she is comfortable with but then abruptly delivers the truth about her 
age -- that she is thirteen years older than Frederick. She tells him, "sometimes [my age] bothered me and other times I looked forward to old-bagness, when I could stop worrying about sex and be like a kid again" (194).

After confiding her thoughts on growing older, Susan continues to play sexually with Frederick and temporarily declines his entreaty to spend time together outside of the sexual arena. Susan contradicts herself, as she does many times throughout the four sub-stories, by being involved in her highly sexual, fantasy-based life and by explaining that she wishes to not have to worry about sex anymore. She signals to Frederick the need she feels for genuine connection but when he proposes they see each other again, she acts coy and argues that she is not ready. She struggles to find the balance between the sexual life she is used to and the authentic relationship she wants to have. Regardless, she and Frederick fool around, drinking and teasing each other sexually. After Frederick leaves her apartment, at the end of "Turgor," Susan sat for "almost an hour, allowing my body to return to aloneness and safety" (200). She has risked having a connection with Frederick and, at the end, feels the need to return to the cocoon of safety within herself. That risk is a big step for her as in doing so, she exposes herself for his judgment. Her usual stance of hiding her true self from others in an attempt to protect her feelings is softened for just a moment behind her sexually intense lifestyle.

"Turgor" ends with the temporary separation of Susan and Frederick, and "Respect" begins with a temporary reconnection. Frederick has left his number in Susan's mailbox after he left at the end of "Turgor." She calls him and they agree to meet. For her date, Susan, who realizes she is afraid of connecting to Frederick on a deeper level than the sexual one they have already explored, links herself to the past by wearing a dress that once belonged to her mother. The memories of her mother and past painful experiences with lovers, which have not been as 
meaningful or as enjoyable as she would like, effects her conversation with Frederick. Being in her mother's dress and having constant memories of the past are set aside, however, when Frederick shows signs of being sensitive and chivalrous: he pulls out her chair, guides on her coat as they are about to leave, and holds the door open for her. These unfamiliar gestures startle Susan and she thinks that, "Maybe, I thought, my fear was a grotesque projection; I decided I mustn't let the past completely distort my experience of the present" (205). Susan recognizes her fear of opening up to others which has stemmed from the negative relationships of her past, but is made hopeful by the sensitive gestures of Frederick and thinks that maybe he will be capable of a different and deeper type of connection.

Despite this hope, Susan's wariness about meeting with and opening up to Frederick is soon confirmed. Having to fit her in between dates with two other girls, Frederick warns her that they will only have three hours together. This is not the type of relationship that Susan is looking for and, as a result, she soon finds that he annoys her. At the end of "Respect," Susan leaves him at her door after their date. She immediately goes to the bathroom, fighting the urge to throw up. Unfortunately, she cannot "discharge the bad feeling so easily" (208). Susan ends this story by telling her cat, “'It's all right,' I told her. 'Don't be afraid. It's not a big deal'” (208). Even though Susan feels a connection to Frederick and finds that she really likes him, she also recognizes that he does not seem to be looking for the same kind of genuine relationship. Nevertheless, her fear of rejection keeps her from reaching out to him to explore the possibility of a more genuine connection. Her rendezvous with the toilet shows her true fear of real connection. She uses her jealousy of his other dates as a reason to back away from him. She feels as though she would be able to have a relationship with Frederick but she is so afraid of actually opening herself up that she finds the prospect of doing so sickening. 
"Processing," the third installment in "The Wrong Thing," brings Erin into the fold. Susan recognizes Erin from the party where she met Frederick and quickly attaches herself to Erin. As they talk, Susan feels Erin try to connect to her and then pull back, as if she is shy (210). Susan recognizes this tendency in herself, which she showed with Frederick, to attach to the other quickly and then question that attachment and this realization endears Erin to her. Erin and Susan talk about their sexual lives and how they have easily slipped into the stereotypical roles of butch bottom and femme top, but Susan says that she is looking for more than that: "I said I was looking for something more genuine, although I didn't know yet what it was. She said she thought she probably was too" (210). When they first kiss, Susan feels a "rush of tension and need" from Erin but they quickly pull back in an effort to maintain some aloofness (211). Susan is attracted by the need she senses in Erin and they spend the rest of the party together. Even though Susan recognizes the "fragility" of their bond, they do not leave each other for the rest of the night (211). Both women have an idea of what they want: a real and genuine connection to someone who reciprocates the same feelings. Since they have no real vocabulary for that type of connection because of their highly sexualized lifestyles, they cannot articulate what they need nor do they have the knowledge of how to go about obtaining it. Therefore, they struggle with and against one another in an ongoing effort to connect.

In their efforts to be genuine, both Susan and Erin explore a "real" sexual relationship with halting movements and continually stop to ask each other if what they are doing is acceptable. Susan, more often than Erin, comforts her new lover. Erin is very nervous about attempting a genuine interaction as she is used to role-playing and masochistic sex. The type of intercourse that she and Susan attempt, however, tries to go beyond the superficiality of that sexual life to connect to the core of their emotional selves. Nevertheless, Susan wakes up the 
morning after her night with Erin feeling "acutely aware of the artificiality" of their interaction (213). Both women have expressed their need and desire for genuine relationship, and Susan is aware that they are unable to reach that point with one another. Their nervousness about trying something new and their fear of truly opening up to someone causes them to fall short of true connection even though they desperately search for it.

Throughout the story, there are glimmers of hope that Susan and Erin will eventually be able to reach the level of connection for which they both yearn. Susan, while visiting Erin at her house, divulges her story about the time she tried to have sex for money. She notes that she realizes she would not be able to tell anyone but Erin this story, emphasizing the possibility for authentic connection that does in fact exist between the two women. Erin pokes fun at her because the man who paid for the sex did not actually do anything to her. He simply put her in a humiliating position: he had her bend over and pull her pantyhose down so he could masturbate (219-20). Through the comedic façade, though, Susan feels Erin trying to reach out and meet her vulnerable confession with some feeling: "it was as if some secret part of her had come out to touch me gently and had then drawn back into its hiding place" (220). While their genuine interactions are minimal and highly experimental, the connection is nonetheless present. Susan and Erin are feeling each other out, making sure they have the potential to be involved in a deep and meaningful relationship. Both are skittish because they are afraid to fully expose their true selves, but Susan makes a phenomenal, exploratory first step towards bringing their relationship to a deeper level by relating one of her most vulnerable and humiliating experiences.

Nevertheless, Susan and Erin falter repeatedly in their attempts to find an authentic level of connection with one another. Susan, in particular, grapples with her feelings for Erin. After a night out with Erin and her friends, Susan pictures Erin in a disturbing way: 
I pictured her staring at me like a frightened animal. I imagined a deep, perpetual moan that racked her body but did not come out of her mouth. I pictured the organs in her abdomen dry as old roots, parched for lack of some fundamental nurture that she has never received and was trying futilely to find. (222)

Susan has tapped into what she thinks is hindering the onset of true connection; Erin is lacking a history that provides nurture and caring. After this mental image, Susan finds that she is no longer attracted to or interested in Erin. She has pictured Erin opening up to her and the thought of that frightens her because it will mimic her own desperate need to open up and her fear of doing the same. Erin senses this change in Susan and reverts back to the comfort of familiar sexual humiliation by slapping tapioca pudding on Susan's crotch (223). This act confirms Susan's fears because Erin, through her sadistic actions, has not allowed the boundary around her to collapse for Susan. Susan has not only pulled herself away from Erin by retreating from the mental image she has of her, but she has also been pushed away by Erin, who refuses to give up role-playing in sex.

After the episode with the tapioca pudding, Susan and Erin argue. Erin leaves and Susan says she feels a "puzzling sensation of triumph at finding myself alone, a sensation that took me happily into sleep" (224). She is comforted by the expected, reliable feelings of being alone, even though it means she is separated from Erin. After two hours of tossing and turning in her sleep though, she wakes up thinking of Erin and wonders about her motives. She realizes at the end of the story, that "everybody wants it [. . ] Erin has it, but she can't bear it" (225). The "it" she refers to is a longing for interaction and connection that allows her to engage on an authentic level. Both women have difficulty allowing themselves to be honest with others, to expose their pain and vulnerability for themselves and others to see. Sadomasochistic role-playing is only a 
superficial defensive mode of connection. Susan is determined to move beyond this while Erin seems incapable of doing so.

"Stuff," the final story in the whole collection and in the cycle "The Wrong Thing," introduces Kenneth, the final character who establishes a connection with Susan. Kenneth notices Susan at yet another party, this one for a screenwriter who has finally sold one of his pieces. The host of the affair calls Susan the next day to ask her permission to share her phone number with Kenneth. When Kenneth calls her, he asks her to go on a date and she accepts with the understanding that they will be going out as friends because Kenneth is in the middle of a divorce. Wary of connection since the failure of her relationship with Frederick and then with Erin, Susan instinctively, to her detriment, falls back into the habit of approaching new situations by depending on her past experiences. For her date with Kenneth she wears the same dress she wore to see Frederick: "On the evening of our date, I decided to wear the dress I had worn for my two hour appointment with Frederick" (235). She has already distanced herself from Frederick, whom she sincerely liked, and continues to do so by categorizing her final meeting with him as an appointment rather than a date. She cannot completely separate herself from her past experiences, though, as she shows by wearing her mother's dress and referring to Frederick.

Once she and Kenneth are at dinner, however, Susan wonders what it would mean to get to know Kenneth: "I realized that across from me sat an unknown person, full of thoughts and feelings I had never had. But it seemed that to get to them, I would have to pry them out of their balled shapes" (236). Susan, once again, shows her eagerness for meaningful connection as she considers how she can relate to this new acquaintance. Since they have agreed to a platonic relationship, sexual pressure is not an issue. Susan can therefore get to know Kenneth as a person without sexual expectations. According to what she told Frederick during their first 
encounter, this is exactly what she has been waiting for: "I looked forward to old-bagness, when I could stop worrying about sex and be like a kid again" (194). Her first meeting with Kenneth offers Susan a glimpse of hope that she does have the capacity for authentic connection that does not pivot on sex.

Similar to her experience with Frederick, however, Susan's second date with Kenneth does not go as smoothly as the first. As she finds out more about him, she realizes that she dislikes him and that he is no better than Frederick or any of the other men she has dated. She begins to hate him after he relates a story about a particular ex-girlfriend. His ex-girlfriend, who he says resembles Uma Thurman, was perfect in his eyes. When she told him that she was thinking about getting breast implants, Kenneth started to see the superficiality that was hidden beneath her gorgeous exterior. In his conversation with Susan, however, he reveals his own superficiality: “'Being with her was like nothing else,' he said. 'It was like having a beautiful Cartier watch on your wrist"' (240). This equation of a young woman with an inanimate object, an expensive and socially high-standing object at that, infuriates Susan. Susan, who desperately wants to be able to connect to someone on a deep and intimate level, cannot understand why she continues the holding pattern of trying to get to know someone only to discover that she could never spend enough time with them to reach the deep level of connection she yearns for. As she says, "My loathing depressed me. It seemed arrogant and stupid" (241). She cannot break out of the habitual dynamic of pursuit and retreat she has created for herself. Despite her desire for genuine intimacy, she is frightened and distrustful of others.

Erin continues to remain in the background as Susan explores her link with Kenneth. The two women, who go out with Erin's roommates to celebrate the end of Susan's semester, still go back and forth with their connection. Susan tells her, as Erin is into masochistic sex, that she 
does not think Erin deserves that kind of treatment. Even though she understands being able to take pleasure from those kind of experiences, she argues that Erin thinks she deserves the punishment. When Erin says that, "It's not about self-hate or anything icky. It just gets me off," Susan can feel them moving away from each other (252). Susan desperately wants to move away from the sexual fantasies but cannot convince Erin to do the same.

At the end of the night, though, Erin invites Susan to accompany her back to her house to release ladybugs into her healing garden. Stepping out into the moonlight to release the ladybugs so that "they'll settle in to sleep and then wake up in paradise," Susan experiences a sort of mystical harmony in the garden (253). She says,

I felt loneliness so strong it scared me. Then Jana laughed and Erin brushed by me, thoughtlessly caressing my spine with one hand. I was in a garden with my friends. I could not fully see what lay about me, but still, I knew it was there, abundant, breathing, and calm. (254)

Susan at last feels peace with her friends. The comfort she feels in the garden shows she is ready to be engaged with these other women on a real and genuine level. The loneliness she encounters scares her and she wants the connection with her friends to be nurtured. Juxtaposed against the comfort her aloneness once afforded her, this signifies a big change in her point of view of relationship. Susan acknowledges her loneliness and isolation, but is also able to experience a consoling sense of coming together with the other women, if only for this one moment in the garden.

Ending her collection with this hopeful cycle, Gaitskill offers a positive message that is at the same time threatening because it puts into question the faux safety of isolation. If one is able to open up to another, to show vulnerability, then connections would become truer and more 
genuine. Confronting the aloneness that many deal with would allow the understanding that there are other people who deal with the exact same issues. The isolation would, in turn, lead to a sense of community. 


\section{Afterword}

Thinking about the short story collection as a genre supports the view of relational psychoanalysis. The interdependence and independence of each story in each collection speaks to the role of the other in the formation of the self. Each story is strengthened by its inclusion in the whole collection as its relation to the other stories enhances the reader's understanding of the entire collection, as well as each individual story. The same is true for the individual. The individual's relationships to others and community are vital for identity formation. The self cannot be understood outside of the relational context.

The protagonists in each collection all share a common bond: their ordeals stem from their struggle to establish and maintain connection to others. Although the circumstances certainly change in each story, the underlying thematic tension between isolation and community ties the stories together. For the different protagonists in these three collections, the struggle to establish and maintain relationship defines the core tension and conflict. Their guarded approaches to new relationships serve as boundaries that become almost insurmountable. The only way they can overcome those obstacles is to reach into themselves and find the courage to expose their own vulnerability.

Each collection offers a different approach to the exploration of the tension between isolation and community. Z. Z. Packer's collection explores this isolation-connection trope through the lens of racial interaction. The protagonists of her collection try to fit into societal structures that reflect racial expectations. Their failure to do so, however, stems from their inability to authentically connect to others. The protagonists experience racial rejection that keeps them defensive and closed within themselves. In "Brownies," the mysteriousness of the white girls in Troop 909 threatens Laurel and her friends, and prompts Laurel to question and 
then finally to find her place in her group through her unspoken bond with Daphne. In "Drinking Coffee Elsewhere," Dina is isolated from her Yale community, starting with the orientation leader's remarks that she does not have to fit in to the white community's standards and games because she is black. Dina struggles with this imposed role and though she emerges from her shell to make contact with Heidi briefly, she is too wounded and defensive to sustain the connection. In "Speaking in Tongues," too, Tia is confronted with the different markers of racist attitudes in the bus station before she runs away to Atlanta, and then with Marie and the other people she meets. Though Tia is in more jeopardy than other Packer characters, her story ultimately suggests more faith in human goodness and generosity, and in the potential for human connection.

Jhumpa Lahiri's collection approaches the friction of isolation and community through characters who are in some way displaced from their comfort zone. Romantic illusions inhibit her protagonists as they search for genuine relationship. Their idealizations shatter, however, when they realize the truth about the people with whom they try to connect. In "A Temporary Matter," Shukumar's hopes of the revival of his relationship with his wife are shattered when she reveals that she has found her own apartment and has established her own separate life. "Interpreter of Maladies," by the same token, depicts Mr. Kapasi and his broken fantasy when he realizes that Mrs. Das is harboring secrets that shatter his illusion about her. In "Sexy," Miranda attempts to foster an intimate relationship with Dev. Her illusion of a romantic relationship, however, is crushed when Dev does not meet her idealizations about him and their relationship. Lahiri's characters all struggle to break through false illusions of connection. This may lead to isolation or aloneness, but only out of such honest self-recognition will genuine connection with others be possible. 
Mary Gaitskill's collection explores the same tension but through the lens of sadomasochistic sexual experience and fantasy. All of Gaitskill's protagonists search for authentic connection but are mostly unable to obtain it because of their own entrapment in sexual fantasy, which often stems from past sexual trauma. In "The Blanket," Valerie initiates a sexual fantasy life with Michael and for some time refuses to submit to the connection she feels with him. Her traumatic past not only causes her to shield her true self behind fantasy, but in this story it is the preemptor for their realization of true connection. "The Dentist" shows Jill as she desperately tries to connect to George. She cannot do so, though, because of her need to fall back on sexual fantasy which is rooted in her traumatic past. This, in turn, causes George to flee from her. In "The Wrong Thing," finally, we see some hope with Susan and Erin. While her relational journey is rough, Susan comes to a final glimmer of hope with Erin. The final scene in the healing garden with the other women suggests that Susan is ready to reveal her vulnerability to herself and to Erin, and it offers a vision of female community as Susan recognizes her bonds to these other wounded yet resilient women.

The stories I have discussed all focus on the importance of relationship in people's lives and their sense of identity. When these characters learn to open up to others, they are better able to understand and be themselves. The prospect of exposing one's vulnerability, however, can be terrifying. The tension that results from protecting one's vulnerable individuality while still desiring connection and community prevails in all three collections. The stories do not always resolve this tension, but simply by expressing it, they offer insight into the dynamics of human relational life. 


\section{Works Cited}

Baldwin, Kenneth H., and David K. Kirby, eds. Individual and Community: Variations on a Theme in American Fiction. Durham: Duke UP, 1975.

Benjamin, Jessica. Shadow of the Other: Intersubjectivity and Gender in Psychoanalysis. New York: Routledge, 1998.

Brada-Williams, Noelle. "Reading Jhumpa Lahiri’s Interpreter of Maladies as a Short Story Cycle.” MELUS 29.3/4 (Fall/Winter 2004): 451-64.

Caplan, Paula J. Between Women: Lowering the Barriers. Toronto: Spectrum Publications, 1981.

---. The Myth of Women's Masochism. New York: E.P. Dutton, 1985.

Davis, Rocío G. “Identity in Community in Ethnic Short Story Cycles: Amy Tan's The Joy

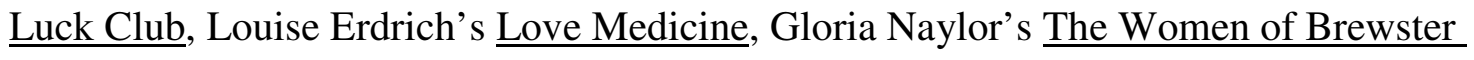
Place. Ethnicity and the American Short Story. Ed. Julie Brown. New York: Garland Publishing, 1997. 3-23.

Dunn, Maggie, and Ann Morris. The Composite Novel: The Short Story Cycle in Transition. New York: Twayne Publishers, 1995.

Gaitskill, Mary. Because They Wanted To. New York: Simon \& Schuster, 1997.

Gilligan, Carol. In A Different Voice: Psychological Theory and Women's Development. Cambridge: Harvard UP, 1982.

Herman, Judith. Trauma and Recovery. New York: Basic Books, 1992.

Ingram, Forrest L. Representative Short Story Cycles of the Twentieth Century: Studies in a Literary Genre. Paris: Mouton, 1971.

Jordan, Judith C., et al. Women's Growth in Connection: Writings from the Stone Center. New 
York: The Guilford Press, 1991.

Juhasz, Suzanne. A Desire for Women: Relational Psychoanalysis, Writing, and Relationships Between Women. New Brunswick: Rutgers UP, 2003.

Lahiri, Jhumpa. Interpreter of Maladies. New York: Houghton Mifflin, 1999.

---. "My Two Lives.” Newsweek. 6 March 2006. 2 March 2006. <http://msnbc.msn.com/id/ 11569225/site/newsweek>.

McCabe, Marilyn. The Paradox of Loss: Toward a Relational Theory of Grief. Westport: Praeger, 2003.

Miller, Jean Baker. Toward a New Psychology of Women. $2^{\text {nd }}$ ed. Boston: Beacon Press, 1986.

Mitchell, Stephen A. Relational Concepts in Psychoanalysis: An Integration. Cambridge: Harvard UP, 1988.

Packer, Z.Z. Drinking Coffee Elsewhere. New York: Riverhead Books, 2003.

Schapiro, Barbara Ann. Literature and the Relational Self. New York: New York UP, 1994.

---. “Trauma and Sadomasochistic Narrative: Mary Gaitskill's 'The Dentist.”” Mosaic 38.1 (June 2005): 37-52..

TuSmith, Bonnie. All My Relatives: Community in Contemporary Ethnic American Literatures. Ann Arbor: U of Michigan P, 1993.

Wyatt, Jean. Risking Difference: Identification, Race, and Community in Contemporary Fiction and Feminism. New York: State U of New York P, 2004. 